\title{
Analyzing Consumer Behavior Toward Counterfeit Products: A Systematic Literature Review
}

\begin{tabular}{c} 
Dr. Alaa Eldin Abbass Ali \\
Associate Professor, Department of Business Administration, Faculty of \\
Commerce, Alexandria University \\
\hline
\end{tabular}

\begin{abstract}
counterfeiting is one of the oldest business phenomena in history that has been affecting trade for about 2,000 years, which has been exploded in the recent years. this research aims to analyze marketing literature review on consumer behavior toward counterfeit products. It also aims to identify the research gap for potential studies by concentrating on determinants that affect consumer purchasing behavior toward counterfeit products. To achieve the research objectives the researcher divide the study into two main parts. The first part includes studies that investigate consumer behavior toward counterfeiting. The methodology and the main results of 42 studies published between 2009 and 2019. The current research presents important ideas for future studies on consumer behavior toward counterfeit products.
\end{abstract}

KEYWORDS 
counterfeited branded product, counterfeited luxury brands, counterfeiting, counterfeit purchase intention, attitudes to buying counterfeit, Demographicbased factors, Consumer personal traits,

\section{Analyzing Consumer Behavior Toward Counterfeit Products: A Systematic Literature Review}

\section{Introduction}

Nowadays, counterfeiting has increased drastically and become a serious global dilemma. (Davidson et al., 2017). For example, counterfeiting in the European Union market amounts to EUR 83 billion and the annual loss of 790000 jobs (EUIPO, 2016). Although this generates huge profits for actors in this industry, counterfeiting leads to enormous losses for legitimate companies. According to (Eisend \& Schuchert-Güler, 2006) it is seen as a significant problem to many of businesses, including convenience and household goods, pharmaceutical and automobile. (Staake et al., 2009). The ethical dilemma of counterfeit products is that they can have negative impacts on consumers, manufacturers, and society as a whole. They also facilitate criminal activities as supply chains for counterfeiters are connected to organized crime, sweatshops, and other illegal activities. (Cesareo \& Stöttinger 2015).

Most scholars claim that research is important to understand the various facets of counterfeit production. (Staake et al., 2009; Toklu \& Baran, 2017). The 
general trend of counterfeiting is important to understand as well as clear reasons behind the purchasing of counterfeit products by customers for successful countermeasures. In addition, understanding those reasons may be worthwhile in developing and implementing strategies for counterfeits. Most counterfeit demands concentrated on basic intentions for buying counterfeit products from various perspectives such as monetary, emotional, social or personal perspectives. (Baruonu Latif et al., 2018).

Hence, it is rather essential to comprehend the buyer's motives and behaviors in buying counterfeit products, Therefore, the research objective is to apply for a systematic literature review with a debate approach that extracts and investigate the research that has explored the consumer buying behavior toward nondeceptive counterfeit. In addition, another contribution is that this study aims to clarify the difference among the studies that have examined the direct relationship among factors and the consumer intention to buy counterfeit and the indirect relationship between factors and attitude towards counterfeit, the relations among attitude and consumer intention to purchase counterfeit (indirect effect) and is also going to shed light on the mediator and moderators variables that are usually investigated in these studies.

This research will be organized as follows. In the first part, the background of counterfeit is provided; the research methodology concerning the type of research and data analysis is presented in the second part. The third part shows the findings under three headings: general characteristics, methodological characteristics, and thematic analysis. The last section includes a conclusion and Ideas for future studies. 


\section{1- Problem statement:}

Recently, the incremental increase of the demand on counterfeit products create a wide range of problems for the manufacturers of genuine products includes losing their market share, profits and customer dissatisfaction (Bradley et al.,2019). It is important to know that gains generated from trading counterfeit products come at the expense of the economic loss of genuine manufacturers. Apart from the profits loss, genuine manufacturers have to face with intangible negative repercussions such as brand dilution, loss of goodwill and unavailing investment costs. Unfortunately, consumers of counterfeit luxury goods are oblivious that they are the ultimate losers. First, original manufacturers will have less interest in spending resources on the development of new and better products due to the low sales revenue, Second, consumers of counterfeit goods expose themselves to various kinds of risk such as performance risk, social risk, prosecution risk and psychological risk (Kian,2018).

The main problem of counterfeit products is with luxury products, over the years the quality of counterfeit products has improved in a way that make customers to discover the differences with genuine products became difficult. Stopping the negative effects of counterfeits seems to be insufficient, so the best way to minimize the consequences of selling and buying counterfeits is to analyze the consumer behavior toward this type products (Ahmad\&Hussain2016). Based on the aforementioned discussion the research problem of this study can be briefly summarized in the following question:

What are the factors falling behind consumer attitudes, intentions and behaviors to purchase counterfeit products? 


\section{2- Research objectives:}

To answer the research question, this study is aims to achieve the following objectives:

2-1- To analyze the studies that have explored determinants that affect customer intention toward counterfeit products.

2-2- To understand consumer attitudes toward counterfeit products by studying a ten-year span of articles that covers the demand side of counterfeit, from the consumer point view as for the buying of counterfeit goods.

2-3- To scan marketing literature review in consumer buying behavior toward counterfeit products.

\section{3- Research importance:}

Since this study tends to investigate factors affecting consumers' attitudes, intention and behaviors towards counterfeit products, results and recommendations benefit authors, researches, genuine brand marketers, market researchers, the society and the government. Hence, this implies both academic and practical importance which will be briefly summarized as follow:

\section{3-1-Academic Importance:}

3-1-1-This study can be used as a secondary data for future studies which consider as a step ahead toward building a comprehensive framework to understand consumer behavior toward counterfeit products.

3-1-2-this study helps in conceptualizing the factors affecting on consumer behavior toward counterfeit products. 
3-1-3-This research is considered one of the few studies which cover 10 years in analyzing consumer behavior toward counterfeit products and investigating all variables affecting on consumer behaviors

\section{3-2-Practical Importance:}

3-2-1-This research findings help in protecting the genuine brands manufacturers from dramatic monetary losses and tarnish losses in brand equity and brand image.

3-2-2-The main contribution of this study is laying in analyzing consumer motives to purchase counterfeit products and this will help mangers to better understand customer needs and wants to by this type of products.

3-2-3- The findings of this study help the decision makers in genuine manufacturing companies and policy makers in Egyptian government to reduced the demand on counterfeit products to protect the property rights and customers against the potential risks of this kind of products.

\section{The research background:}

Counterfeiting is identified as goods with the same mark, or barely distinguishable from a trademark registered with another party and violating the holder rights of the trademark (Chaudhry \& Walsh, 1996). While the first research can be traced back to the 1970s, imitation remains a popular topic with a growing multidisciplinary theme (Staake et al., 2009). Particularly in the last dozen years, growing customer demand for counterfeiting has stimulated considerable interest in researchers investigating the phenomenon from multiple angles, thus the topic has been studied by various disciplines, such as business, ethics, logistics, law and marketing(Staake et al., 2009). 
In general, related counterfeiting research can be categorized into three groups: supply side, demand side, and global/local economy side (Staake et al., 2009). The supply side appeared to concentrate on strategies employed by product counterfeiters (Stevenson \& Busby, 2015), illegal distribution channels (Cho et al., 2015), Characteristics of production/producers (Green \& Smith, 2002), productivity (Amine \& Magnusson, 2007). The demand side focused on the attitudes of buyers to purchase counterfeit brands (Augusto de Matos et al., 2007), Intention to buy (Eisend et al., 2006), Characteristics of the customers (Cheung \& Prendergast, 2006), Determinants of consumer buying behavior (Eisend et al., 2017; Staake et al., 2009), Decision making process on counterfeit goods (Gentry et al., 2001).

\section{Research Methodology:}

Recently, there has been a large amount of the information available as a result of the continuously evolving online distribution and the new journals and conferences have raised the desire for more review methods to better enhance current conclusions, along with the incremental value of literature review as a basis for improving scientific research. (Fawcett et al., 2014). Bearing this in mind, Systematic literature review (SLR) was preferred to ensure that no major study was ignored and to enhance quality, scientific rigor and bias minimization. (Tukamuhabwa et al., 2015).

\subsection{A systematic review}

Based on the guidelines drawn up by Colicchia \& Strozzi (2012), the current SLR was undertaken in three stages based on research questions. Clarity, 
feasibility, and compatibility with current questions of the study are critical in guiding the SLR and in supporting its results (Jesson et al., 2011).

The aim of this research is, therefore, to analyze the literature to comprehend factors influencing the buyer's attitude and intention toward counterfeit brands. In this context, systematic literature review of this research began with one question from a wider perspective:

What are the variables that influence customer attitude and intention toward counterfeit goods?

\subsection{Criteria for including and excluding Articles of this study}

The research included in this study were scientific peer-reviewed research articles that reported factors that influence consumer counterfeit purchasing behavior, hence, magazine articles, books, articles from conferences were excluded. Also, for these studies to be inclusive, they must have dealt directly with factors/determinants/variables of consumer counterfeit purchasing behavior; therefore, if they didn't directly mention or deal with factors, determinants, variables that could affect consumer behavior when buying counterfeit products were excluded from this systematic review. This review applied a language restriction on the search results, only studies that have full content written in English were inclusive, Table 1 summarizes both inclusion and exclusion requirements for that study.

Table 1 Criteria for inclusion and exclusion

\begin{tabular}{|l|l|l|}
\hline Criteria & Inclusion & Exclusion \\
\hline
\end{tabular}




\begin{tabular}{|l|l|l|}
\hline Quality of the Journal & Periodic peer-reviewed research. & $\begin{array}{l}\text { Business magazines, conference, } \\
\text { books and notes. }\end{array}$ \\
\hline Access & Total material collected in English & $\begin{array}{l}\text { The full content is not written in } \\
\text { English. }\end{array}$ \\
\hline The alignment of & Demand side of counterfeit & $\begin{array}{l}\text { Supply side of counterfeit, } \\
\text { strategies that deals with } \\
\text { counterfeit. }\end{array}$ \\
\hline Focus & $\begin{array}{l}\text { Deal directly with factors/determinants of } \\
\text { consumer counterfeit purchasing } \\
\text { behavior. }\end{array}$ & $\begin{array}{l}\text { Not deal directly with } \\
\text { factors/determinants of consumer } \\
\text { counterfeit purchasing behavior. }\end{array}$ \\
\hline Study Design & $\begin{array}{l}\text { Empirical studies } \\
\text { Clearly mention causes/ factors, variables } \\
\text { that affect/influence consumer behavior to } \\
\text { purchase counterfeit goods. }\end{array}$ & $\begin{array}{l}\text { Not clearly mention variables/ } \\
\text { determinants, antecedents that } \\
\text { affect/influence consumer } \\
\text { behavior to purchase counterfeit } \\
\text { goods. }\end{array}$ \\
\hline
\end{tabular}

Source: The Author

\subsection{Searching the literature}

This paper is a systematic review study, concerned with the factors that affect consumer counterfeit purchasing behavior. The databases that have been searched for the purpose to find relevant research articles are Emerald insight, Science Direct (Elsevier), Wiley, and Sage. Such two sources have been regarded in the area of management and social sciences because of their coverage of publications.

The search covered the period from year January 2009 up to April 2019; hence this paper is going to cover a ten-year span of articles that covers the demand side of counterfeit, meaning the consumer point view as for the buying of counterfeit goods. The following main search terms were used in conjunction 
with the identification of related articles:" factors, determinants and variables"; "counterfeit"; " consumer counterfeit purchasing behavior", and " demand side of counterfeit", " copycat ", "fake "

As mentioned before, this research included published studies during the last 10 years from 2009 till 2019 where the counterfeit issues in recent years have increased substantially (Kamalahmadi \& Parast, 2016; Linnenluecke, 2017). Moreover, a literature review was opened to publications in peer-reviewed journals that granted better quality for this paper (Denyer \& Tranfield, 2009). Depending on these keywords, the articles obtained from the four databases were 1847 articles. The aim is to ensure that the focus was on factors and variables that influence consumer behavior toward counterfeiting.

To ensure the consistency of the chosen mate, publications that comply with the inclusion criteria and thus ignore all exclusion criteria have been taken into consideration in the SLR (Tranfield et al. 2003). 42 papers for further research were written. To find common themes and explore the essence of the findings, the content of each article is examined in different dimensions. The review of the articles was carried out by the authors, while the research was categorized into three groups, the first being general characteristics, which entails the number of authors, institutions, countries, location of authors, database, and specific counterfeit products studies in the article. The second subgroup is the methodological aspect which consists of a type of research and design, method of sampling and methods of analysis used in the methodology. The last subgroup is the theme analysis, which is about the theories, variables, and results. 
6. Results: This part provides a brief summary to the results of the study. The results are extracted based on investigating number of studies published between 2009 and 2019 (table2). These results will be classified into three groups which are common characteristics, methodology and thematic analysis

\subsection{Common Characteristics}

Specific characters as mentioned afore were taken as many researchers, institutions, and countries, the location (countries) where the studies were applied, Domain of the journal to which the article is published and, ultimately, whether or not the research concentrate on a particular counterfeit good. According to statistics in general, two writers have written the vast majority of publications. (35.7\%), which is an indicator of the need for counterfeit research collaboration.

As to the number of institutions to which researchers are affiliated, it has been seen that two institutions (50 percent) form the vast majority of publications. And these data indicated that the institutions ' countries were not diverse at all. However, according to our results (88\%) of the studies was applied in a single country, and (7\%) were applied in two countries and $(2.3 \%)$ was applied in three and above countries. on the other hand, interesting to track the author's location so that counterfeit studies are dispersed. Continental analyzes were done and most research studies were carried out in Asia (by 18 researchers), North America and South America (by 13 researchers), Europe (by 8 researchers), Australia (by 6 researchers), Africa (by 3 researchers), Middle East (3 researchers), and China (by 2 researchers). Finally, in the articles, it was also examined whether a specific category of products was considered to be 
preferred as counterfeit products. Most of the articles didn't focus on a given category (17 articles) however it did tend to refer to general counterfeit goods. Also, the second majority was on counterfeit choices made by consumers in the category of accessories (Uhren, handbags, and diamonds.) (15 articles).

Table 2 Overall features of the studies;

\begin{tabular}{|c|c|c|}
\hline Overall features & $\begin{array}{l}\text { Articles } \\
(n=42)\end{array}$ & $\begin{array}{l}\text { Percentage of } \\
\text { studies (\%) }\end{array}$ \\
\hline \multicolumn{3}{|l|}{ Authors Number } \\
\hline One & 4 & $9.5 \%$ \\
\hline Two & 15 & $35.7 \%$ \\
\hline Three & 14 & $33.3 \%$ \\
\hline Four & 8 & $19 \%$ \\
\hline Five & 1 & $2.3 \%$ \\
\hline \multicolumn{3}{|l|}{ Number of countries } \\
\hline One & 37 & $88 \%$ \\
\hline Two & 3 & $7 \%$ \\
\hline Three & 1 & $2.3 \%$ \\
\hline More than three & 1 & $2.3 \%$ \\
\hline \multicolumn{3}{|l|}{ Authors ' location * } \\
\hline Africa & 3 & - \\
\hline America & 13 & - \\
\hline Asia & 18 & - \\
\hline Australia & 6 & - \\
\hline Europe & 8 & - \\
\hline Middle East & 3 & - \\
\hline China & 2 & - \\
\hline \multicolumn{3}{|c|}{ Specific counterfeit goods mentioned in the studies * } \\
\hline Not in a specific category & 17 & - \\
\hline Accessories & 15 & - \\
\hline Clothing & 8 & - \\
\hline
\end{tabular}




\begin{tabular}{|l|l|l|}
\hline Other & 8 & - \\
\hline Number of institutions & 13 & $30.9 \%$ \\
\hline One & 21 & $50 \%$ \\
\hline Two & 4 & $9.5 \%$ \\
\hline Three & 4 & $9.5 \%$ \\
\hline Four & & \\
\hline Database & 19 & $45.2 \%$ \\
\hline Emerald & 5 & $11.9 \%$ \\
\hline Sage & 11 & $26.19 \%$ \\
\hline Science direct (Elsevier) & 7 & $16.6 \%$ \\
\hline Wiley & 7 & \\
\hline
\end{tabular}

Source: The Author

* Note: Articles may be drawn from more than one category

\subsection{Characteristics of methodological method}

The studies investigated counterfeit literature as a methodological aspect in light of the type of research, the research design, the sampling method and the analytical method employed in the studies. The majority of the research was quantitative. (81\%), qualitative (2.4\%) research and combined types (16.7\%), correspondingly, keeping in mind that this study is only examining empirical studies; studies that are not empirical were discarded. Besides, Survey (41) was the most common research design and an in-depth interview followed (5). Finally, as a technique of analysis, the most common ones were CFA/SEM (15 articles). Regression/Correlation (14 articles), Factor analysis (10), TTest/ANOVA/MANOVA(5 articles) and in other words, authors were focused in shedding light on relational outcomes through structural equation model and regression and correlation with other approaches. The majority of the studies 
didn't assign a theory in their study about 23 articles; however, the most widely employed (12). The theory/theories for explaining counterfeit consumption were noticed to be based on the Theory of Reasoned Actions and the Theory of Planned Behavior (see Table 3).

Table 3 Methodology of the research

\begin{tabular}{|c|c|c|}
\hline The overall features & $\begin{array}{l}\text { research } \\
(\mathrm{n}=42)\end{array}$ & $\begin{array}{l}\text { Percentage of } \\
\text { Articles (\%) }\end{array}$ \\
\hline Quantitative & 34 & $81 \%$ \\
\hline Qualitative & 1 & $2.4 \%$ \\
\hline Quantitative and Qualitative & 7 & $16.7 \%$ \\
\hline \multicolumn{3}{|l|}{ Design of research $*$} \\
\hline Survey & 41 & - \\
\hline Experimentation & 3 & - \\
\hline In depth interview & 5 & - \\
\hline Focus Group & 1 & - \\
\hline \multicolumn{3}{|l|}{ Methods of analysis used in this Article * } \\
\hline Correlation/regression & 14 & - \\
\hline T test / Anova test & 5 & - \\
\hline CFA/SEM & 15 & - \\
\hline Factor analysis & 10 & - \\
\hline \multicolumn{3}{|l|}{ Theories used* } \\
\hline Cognitive Dissonance Theory & 1 & - \\
\hline Consumer Demand Theory & 1 & - \\
\hline Functional Theory of Attitudes & 1 & - \\
\hline Moral Competence \& Moral Reasoning Theory & 2 & - \\
\hline Neutralization Theory & 1 & - \\
\hline Perceived Risk Theory & 1 & - \\
\hline Self-Discrepancy Theory & 1 & - \\
\hline Social Identity Theory & 1 & - \\
\hline
\end{tabular}




\begin{tabular}{|l|l|l|}
\hline Theory of Reasoned Action \& Theory of Planned Behavior & 12 & - \\
\hline Theory of Social Control & 1 & - \\
\hline NA (Not Assigned) & 23 & - \\
\hline
\end{tabular}

Source: The Author

* Note: Articles may be drawn from more than one category

6.3 Thematic analysis

This research focuses on the key factors that influence on counterfeit buying behavior, and after examine the literature, it was found that when it comes to studies that investigated the factors that influence counterfeit consumption, There are studies that have explored determinants that affect customer intention toward counterfeit products, whereas other studies have examined the factors that affect customer attitudes to buy counterfeit brands and the mediating impact of the attitude to buy counterfeit brands. Also, other studies examined other mediators and/or moderator affect counterfeit behavior such as product involvement (Ngo et al., 2018; Bian \& Moutinho, 2011), product attribute (Bian \& Moutinho, 2011), product knowledge (Ngo et al., 2018), and perceived counterfeit detection (Wu et al., 2019). Therefore, this paper has conceptualized them under three parts, the first part is the studies that explored factors that affect counterfeit purchase intention (Table 4), The second part is the studies that have examined the factors that affect consumer attitude towards counterfeit (Table 5), and the third part is the mediating impact of the counterfeit goods on counterfeit behavior by other mediators/moderators (Table 6).

\subsubsection{Factors that affect counterfeit purchase intention}

After examination of the literature, factors affecting counterfeit purchase intention have been classified into five categories which are: Demographic- 
based factors, Consumer traits based factors, Product and brand-based factors, Socially-based factors, and the last section is the influence of customer attitude and intention to buy counterfeit products (Summary of all the factors are found in Table 4).

\subsubsection{Demographic-based factors affecting on counterfeit purchase intention}

After examining the extracted articles, it is found that some articles (Swami et al., 2009; Bian \& Monino 2009; Fernandes, 2013; Randhawa et al., 2015) have explored the relationship between demographics and consumer intention to buy counterfeits. Demographic characteristics that have been explored in the extracted articles are age, gender, income, education, and socio-demographic characteristics.

\subsection{The impact of age on customer intention to purchase} counterfeit products:

When examining the extracted studies that have explored the demographicbased category, the results revealed a bit of controversy. To examine the influence of age, some studies indicated that age positively influences $\mathrm{CF}$ purchase intention (Riquelme et al., 2012). Swami et al., (2009) revealed that older people displayed less willingness to buy counterfeit goods. Where other studies stated that age negatively influences CF purchase intention. Fernandes (2013) and Randhawa et al., (2015), found that age has a significant and negative impact on willingness to purchase, indicating that younger consumers are more vulnerable than older consumers to buying counterfeit goods. However, most studies have suggested that age doesn't influence CF purchase 
intention (Bian \& Mountinho, 2009; Hamlin et al., 2012; Poddar et al., 2012, Pratt \& Zeng, 2019).

\subsection{The impact of gender on intention to buy counterfeit goods:}

Almost all of the extracted research that have investigated gender's influence on CF purchase intention (Bian et al., 2016; Norum \& Cuno, 2011; Poddar et al., 2012; Pratt \& Zeng, 2019; Randhawa et al., 2015; Riquelme et al., 2012; Swami et al., 2009) and there was no evidence that gender has any influence on CF purchase intention. For example, Norum \& Cuno (2011) revealed that consumer intention toward counterfeit brands was not significantly affected by gender, However, Hamelin et al., (2013) tested intention to buy counterfeit brands in 3 main categories of goods: clothing, cosmetics, and cellular phones, and customer demographics have been examined in an attempt to profile buyers who are likely to consider purchasing (or avoiding) counterfeit products. Findings indicate that gender has an explanatory force on a socio-demographic level.

\subsection{The impact of income on the intention to buy counterfeit}

goods:

When it comes to the extracted studies that have investigated income, most of the studies on CF purchase intention indicated that and there is no evidence that income have any influence on CF purchase intention (Bian et al., 2016; Hamelin et al., 2013; Norum \& Cuno, 2011; Poddar et al., 2012; Riquelme et al., 2012; Bian et al., 2016; Hamelin et al., 2013; Norum \& Cuno, 2011; Poddar et al., 2012; Pratt \& Zeng, 2019; Randhawa et al., 2015; Riquelme et al., 2012; Swami et al., 2009). Nevertheless, Hamelin et al., (2013) stated that, at a socio- 
demographic level, lower-income buyers were more interested to buy counterfeit goods.

\subsubsection{4 the impact of education on the intention to buy counterfeit} goods:

When exploring the correlation among education and buying intention toward $\mathrm{CF}$, the results were a bit controversy, since some studies showed that education does positively influence on CF purchase intention (Riquelme et al., 2012), and some showed that it negatively influence on CF purchase intention (Pratt \& Zeng (2019), and the majority indicated that education does not influence CF purchase intention ( Biana \& Moutinho, 2009; Swami et al., 2009; Hamlin et al., 2013; Norum \& Cuno, 2011). However, in contrast to these studies, Norum \& Cuno (2011) revealed the level of education is not a substantial variable to influence on consumer intention to buy counterfeit products.

\subsection{The impact of other socio-demographic characteristics:}

Other socio-demographic characteristics that have been examined are affordability (Randhawa et al., 2015), ethnicity (Swami et al., 2009), household size (Hamlin et al., 2013), marital status (Swami et al., 2009; Hamlin et al., 2013), religion, (Swami et al.,; Pratt \& Zeng, 2019) and unemployment (Pratt \& Zeng, 2019). Affordability, ethnicity, marital status, and unemployment showed that they don't influence CF purchase intention, whereas, Household size indicated that it negatively influences CF purchase intention (Hamlin et al., 2013). Also, Religion had contradictory results one study stated that religion 
negatively influence CF purchase intention (Pratt \& Zeng, 2009), but another study indicated that religion doesn't influence CF purchase intention (Swami et al., 2009)

6.3.1.2 Consumer personal traits specific motivations effect on the intention toward buying counterfeit goods:

The second category is the research that has analyzed the effect of customer personal traits on the intention to buying counterfeit products. Many of the research analyze consumer preferences toward counterfeits by focusing on the personal and demographic characteristics of the buyers. Most mentioned (repeated in more than 3 studies) personality traits was found in the examined studies are materialism, Integrity, ethical/morality, religiosity, value consciousness, and perceived risk (other factors are summarized in Table 4).

\subsection{The impact of materialism on the intention of purchasing} counterfeit products:

Materialism is the importance of worldly possessions for the consumer (Belk, 1985). Materialists see the acquisition of possessions as a way to attain pleasure (Richins \& Rudmin, 1994). After examining the studies, it is found that most of the studies that have investigated personality traits inspected the variable materialism; some have found that materialism has no effect on the intention to purchase counterfeit goods and some had a negative impact on the purchasing of counterfeit goods. In the following years, Kozar \& Marcketti (2011) have shown that buyers that are less materialistic and have profound ethical values are less likely to buy counterfeit clothing. Trinh \& Phau (2012) noted that no materialism has been stated to be related to the usage of counterfeit goods. 
Similarly, Kaufman (2016) stated the materialism's effect on the buying intention toward either original or counterfeit products to be modest but significant.

\subsection{The impact of ethical concerns on counterfeit purchase}

intention:

Tang et al. (2014) indicated that ethical concerns accounted for approximately $10 \%$ of the motives to buy counterfeit goods. Quoquab et al. (2017), however, stated that ethical issues influence the actions of customers directly and indirectly when they buy counterfeit goods. However, Nagar \& Sing (2019) contrary to previous findings and unlike previous results, have shown that ethics and a willingness to buy counterfeit fashion clothing were found to be correlated. In general, Lee \& Workmen (2011) has not stated any significant differences in consumer ethics among counterfeit users and non-users though the benefit of counterfeit buyers was less than the benefit of non-purchasers. Souiden (2018) demonstrates that ethics and attitudes all affect intention to purchase counterfeit products. Furthermore, Alfadl et al. (2014) stated that consumer awareness of the social implications of unethical buying behavior does not affect counterfeit drug shopping in Sudan. The findings stated also, that the decision to be associated with this unethical purchasing activity is not socially stigmatized. While it is ethical and legal to buy counterfeit products, Sudan's consumers also accept such purchasing decisions as reasonable (Alfadl et al., 2014)

6.3.1.2.3 The impact of moral antecedents on the intention to purchase counterfeit products: 
Kim et al., (2009) analyzed the direct impacts of personal morality, moral strength, and moral impact, particularly shame and guilt, on intention to buy counterfeits goods. The indirect impacts of moral strength, shame, and guilt on judgment were also examined. Moral judgment influenced negatively the on intention to buy both the counterfeit and imitation goods. Moral intensity did not have a significant effect on the intention to purchase all types of goods, but it also had a significant positive impact on the moral judgment for all types of goods. (Kim et al., 2009). Guilt had a negative impact on the intention to buy goods on the gray market and a positive effect the moral judgment of all types of goods. Furthermore, the moral judgment mediated the impact of guilt on the buying of gray market goods (Kim et al., 2009). Martinez \& Jaeger (2016) have underlined the value of moral knowledge as a key aspect of personal decisionmaking. Moral feelings have also been found to affect moral judgment and the desire to purchase.

6.3.1.2.4 The impact of perceived value on the intention to buy counterfeit products:

Value-conscious buyers usually have a favorable attitude about counterfeit goods (Phau \& Teah, 2009), since they prefer to buy cheap goods of limited quality, along with the basic functions required and the symbolic implications of counterfeit goods are met (Wang et al., 2005). In addition, consumer attitudes mediated the impact of value-consciousness on the buyer's buying intention to buy counterfeit luxury products. Findings by Fernandes (2013) and Randhawa, et al., (2015), also shows that value awareness has had a positive effect on the buyer's intention to buy counterfeit goods. 


\subsection{The impact of perceived risk on intention to purchases}

counterfeit products:

Perceived risk is the commonly studied variable in the marketing domain (Mitchell, 1999), and much work has been carried out on the impact of perceived risk to understand the actions and consumer behavior (Forsythe \& Shi, 2003). Generally, consumers with a lower social class purchase counterfeit products in such a way that they can assume a higher position, with less risk tolerance between them, as they are already conscious of a lower standard of product quality (Wang et al., 2005). And reap the advantages of the genuine brand name without paying a higher price (Gentry et al., 2006). As mentioned above, the perceived risk includes multiple risks, and after examining the studies, the risk types that are then discussed in the extracted studies are economic threats, societal hazards, physical and psychological risks, proceedings. Bian \& Moutinho (2011) the financial risk was found not to be a key deterrent when the consumers buy counterfeit goods. However, Tang et al (2014) claimed that the second described that a strong incentive to buy counterfeit goods, whether physical or social risk, is viewed as a risk. Similarly, Koay (2018) showed that performance risk is a key factor affecting buyer behavior to buy counterfeit luxury goods. Consequently, Xiao et al., (2018) revealed that, when consumers believe that there is a high risk of using a counterfeit good, they feel compelled to stifle the positive buying intention caused by actual-ideal self-discrepancy. Koay (2018) inspected four risk components impacting consumer intention to buy counterfeit goods; the study revealed that performance risk and social risk are key antecedents to purchase 
counterfeit luxury goods. In addition, the social risk was stated to be strongly affected the desire of customers to buy counterfeited luxury products. The research reveals that customers are much less willing to buy counterfeit goods unless they feel that the discovery of the truth is embarrassing and shameful (Herstein et al., 2015). On the other hand, the two other risk components that are a marginal link among psychological threat and intention to buy, indicate that while students may have psychological stress when buying genuine luxury products, the perception of psychological risk is not sufficient to affect their intention to buy counterfeit luxury products. Furthermore, the prosecution's risk was concluded to have no significant correlation with the buying intention and this result is compatible with that of Riquelme et al. (2012).

\subsubsection{Product-based factors affecting on counterfeit buying intention}

Some of the product and brand specific-factors that were mentioned in the extorted studies were: product involvement, product knowledge, product attributes, and brand consciousness. In this part, a summary will be discussed.

Bian \& Moutinho (2011b) stated that buyers for counterfeit goods perceive it as being in the best design, practicality, better quality, fun and value for money than non-buyers. The goods are more cheerful, autonomous, consistent, healthy, optimistic and classic for counterfeit branded customers than non-buyers in terms of brand personality. Ngo (2018) also found that a person's knowledge of a product may affect the expected buying of counterfeit products. Bian \& Moutinho (2011a) also indicated that the personality of the brand has a more leading role in the intention to buy counterfeit goods by consumers than the product's features. 


\subsubsection{Social-based factors affecting on counterfeit purchase intention}

Investigating studies that emphasize the social dimension of using counterfeit goods revealing that the most social factors were collectivism (culture), social norms, and status consumption (Omeraki Çekirdekci \& Baruonu Latif, 2019). In the coming section, the relationship among social variables and $\mathrm{CF}$ consumer intention is going to be discussed; the other correlation among social variables and consumer's attitude is going to be discussed in later part of this paper.

6.3.1.4.1 The impact of collectivism on customer intention to purchase counterfeit goods:

The majority of academics stated that buyers are purchasing and using counterfeit products due to their culture. Lee \& Workman (2011) investigated a culture component by comparing two culturally different participants on copied items with different values, and It has revealed that Korean students are more likely than American students to purchase counterfeit and had more favorable attitudes to buying it, because Korean students are less likely to consider counterfeits as valuable alternatives to genuine goods than US students. Pau \& Teah (2009) focused on collectivism, which influences Chinese consumers ' attitudes to buying counterfeit genuine products and how these factors affect buying behavior, they found that collectivism had no any effect on buyer intention to buy counterfeit goods, however.

6.3.1.4.2 The impact of social norms on counterfeit buying intentions 
Wu et al., (2019) compared the consumer buying intention toward counterfeit athletics products among students from Singapore to Taiwan. The results showed that subjective norm had the strongest effect on consumer intention to purchase counterfeit goods. The result that subjective norms have had a stronger effect than attitudes in either motivating or inhibiting consumer intention to deliberately buying counterfeit goods may be attributable to China's collectivist culture. In addition, Tang et al. (2014) found that subjective norms account for about $10 \%$ of the reasons why counterfeit goods are purchased.

6.3.1.4.3 The impact of the consumption status on the intention toward counterfeit products

Consumption status is a driving force for people who want to boost their social standing by buying goods that build an image. (Phau et al., 2009) revealed that status buyers have to have products that embody their ego-identity, to be more conscious of the exhibition of achievement and have a negative attitude in favor of counterfeit luxury products (Phau \& Teah, 2009; Phau et al., 2009; Harun et al., 2012). Phau et al., (2009) point to the indicators of status, such as apparel buyers may choose apparel that conveys their leisure-status and autonomy from job duties to confirm their unique status. Although consumption status has had no significant effect on the attitudes to buy the legitimacy of counterfeit luxury goods, status consumption affected buyer attitudes against the legitimacy of the buying of luxury counterfeit brands.

\subsubsection{The impact of consumer attitude on intention toward counterfeit goods}

Most of the studies that inspected the relationship among attitude to counterfeit goods and counterfeit buying intention reported that attitude to buying 
counterfeit products positively impacts counterfeit purchase intention. For example, Phau \& Teah (2009), revealed that attitude to buying counterfeits goods does indeed affect consumer buying intentionSimilarly, Souiden et al., (2018) also reported that attitudes influence the intention to buy counterfeits. Correspondingly, Teah et al., (2015) indicated that attitudes towards counterfeit luxury goods affect customer buying intention. Norum \& Cuno (2011) also support these results since their study and suggests that behavioral changes may be necessary to deter demand for counterfeit products. The study carried out by Bhatia (2018) indicated that the attitude of buyers to purchase counterfeit fashion brands affect positively consumer buying intention. In addition, Jiang et al. (2019) found that this attitude positively affects the intention toward the counterfeits. Lee \&Workman (2011) reported that there is a strong relationship between attitudes, intentions, and behavior; hence, counterfeit buyers have much more favorable attitudes towards counterfeits. Phau et al., (2009), however, analyzed the relationship among attitudes and intentions to buy counterfeit luxury products, but it has been noticed that buying attitudes have no impact on consumer desire to buy these types of goods.

Table 4 Summary of findings of factors affecting on CF purchase intention

\begin{tabular}{|l|l|l|l|l|}
\hline \multicolumn{2}{|l|}{ Dependent Variable: Intention toward counterfeits } \\
\hline $\begin{array}{l}\text { Independent } \\
\text { Variables }\end{array}$ & Citations & Positive & Negative & $\begin{array}{l}\text { Not } \\
\text { significant }\end{array}$ \\
\hline Demographic Characteristics & & & $*$ \\
\hline \multirow{4}{*}{ Age } & Biana \& Moutinho (2009) & & & $*$ \\
\cline { 2 - 6 } & Hamelin et al., (2013) & & $*$ & \\
\cline { 2 - 6 } & Randhawa et al., (2015) & $*$ & & \\
\hline & Riquelme et al., (2012) & & & $*$ \\
\hline
\end{tabular}




\begin{tabular}{|c|c|c|c|c|}
\hline & Swami et al., (2009) & & $*$ & \\
\hline & Poddar et al., (2012) & & & $*$ \\
\hline & Pratt \& Zeng (2019) & & & $*$ \\
\hline Affordability & Randhawa et al., (2015) & & & $*$ \\
\hline \multirow{6}{*}{ Education } & Biana \& Moutinho (2009) & & & $*$ \\
\hline & Hamelin et al., (2013) & & $*$ & \\
\hline & Norum \& Cuno (2011) & & & $*$ \\
\hline & Riquelme et al., (2012) & $*$ & & \\
\hline & Pratt \& Zeng (2019) & & $*$ & \\
\hline & Swami et al., (2009) & & & $*$ \\
\hline Ethnicity & Swami et al., (2009) & & & $*$ \\
\hline \multirow{7}{*}{ Gender } & Biana \& Moutinho (2009) & & & $*$ \\
\hline & Hamelin et al., (2013) & & $*$ & \\
\hline & Norum \& Cuno (2011) & & & $*$ \\
\hline & Poddar et al., (2012) & & & $*$ \\
\hline & Pratt \& Zeng (2019) & & & $*$ \\
\hline & Randhawa et al., (2015) & & & $*$ \\
\hline & Riquelme et al., (2012) & & & $*$ \\
\hline Household size & Hamelin et al., (2013) & & $*$ & \\
\hline \multirow{5}{*}{ Income } & Biana \& Moutinho (2009) & & & $*$ \\
\hline & Hamelin et al., (2013) & & $*$ & \\
\hline & Norum \& Cuno (2011) & & & $*$ \\
\hline & Poddar et al., (2012) & & & $*$ \\
\hline & Riquelme et al., (2012) & & & $*$ \\
\hline \multirow{2}{*}{ Marital Status } & Hamelin et al., (2013) & & & $*$ \\
\hline & Swami et al., (2009) & & & $*$ \\
\hline \multirow{2}{*}{ Religion } & Pratt \& Zeng (2019) & $*$ & & \\
\hline & Swami et al., (2009) & & & $*$ \\
\hline Unemployment & Pratt \& Zeng (2019) & & $*$ & \\
\hline \multicolumn{5}{|l|}{ Personal Traits Factors } \\
\hline Actual-ideal self & Xiao et al., (2018) & $*$ & & \\
\hline
\end{tabular}




\begin{tabular}{|c|c|c|c|c|}
\hline discrepancy & & & & \\
\hline $\begin{array}{l}\text { Appeal to higher } \\
\text { loyalties }\end{array}$ & Koay (2018) & & & $*$ \\
\hline \multirow{2}{*}{$\begin{array}{l}\text { Attitude towards } \\
\text { Lawfulness }\end{array}$} & Phau et al., (2009b) & & & $*$ \\
\hline & Swami et al., (2009) & & $*$ & \\
\hline $\begin{array}{l}\text { Concern about } \\
\text { apparel industry } \\
\text { Issues }\end{array}$ & Marcketti \& Shelley (2009) & $*$ & & \\
\hline $\begin{array}{l}\text { Condemnation of } \\
\text { the condemners }\end{array}$ & Koay (2018) & & & $*$ \\
\hline $\begin{array}{l}\text { Counterfeit } \\
\text { Proneness }\end{array}$ & Sharma \& Chan (2016) & $*$ & & \\
\hline Denial of Injury & Koay (2018) & & & $*$ \\
\hline $\begin{array}{l}\text { Denial of } \\
\text { Responsibility }\end{array}$ & Koay (2018) & $*$ & & \\
\hline $\begin{array}{l}\text { Denial of the } \\
\text { victims }\end{array}$ & Koay (2018) & $*$ & & \\
\hline \multirow{3}{*}{ Ethical Judgement } & Fernandes (2013) & & $*$ & \\
\hline & Martinez \& Jaeger (2016) & & $*$ & \\
\hline & Sharma \& Chan (2016) & $*$ & & \\
\hline \multirow{3}{*}{ Ethical value } & Kozar \& Marcketti (2011) & & $*$ & \\
\hline & Lee \& Workman (2011) & & & $*$ \\
\hline & Nagar \& Singh (2019) & $*$ & & \\
\hline $\begin{array}{l}\text { Fashion } \\
\text { consciousness }\end{array}$ & Fernandes (2013) & & & $*$ \\
\hline Fear of Authority & Hamelin et al., (2013) & & & $*$ \\
\hline $\begin{array}{l}\text { Fear of divine } \\
\text { punishment }\end{array}$ & Souiden et al., (2018) & & $*$ & \\
\hline Financial risk & Biana \& Moutinho (2009) & & & $*$ \\
\hline Guilt & Kim et al., (2009) & & $*$ & \\
\hline Health concerns & Hamelin et al., (2013) & & $*$ & \\
\hline
\end{tabular}




\begin{tabular}{|c|c|c|c|c|}
\hline Hedonic Benefits & Kaufmann et al., (2016) & $*$ & & \\
\hline Idealism & Souiden et al., (2018) & & & $*$ \\
\hline Impulsive buying & Randhawa et al., (2015) & $*$ & & \\
\hline \multirow{4}{*}{ Integrity } & Hamelin et al. (2013) & & $*$ & \\
\hline & Phau et al., (2009a) & & $*$ & \\
\hline & Phau et al., (2009b) & & $*$ & \\
\hline & Phau \& Teah (2009) & & $*$ & \\
\hline \multicolumn{5}{|l|}{ Moral Belief } \\
\hline Moral Emotions & Martinez \& Jaeger (2016) & & $*$ & \\
\hline Moral decoupling & Orth et al., (2019) & $*$ & & \\
\hline Moral Intensity & Kim et al., (2009) & & & $*$ \\
\hline Moral Risk & Pueschel et al., 2016 & & $*$ & \\
\hline Moral Judgement & Kim et al., (2009) & & $*$ & \\
\hline \multirow[t]{7}{*}{ Materialism } & Kaufmann et al. (2016) & & & $*$ \\
\hline & Kozar \& Marcketti (2011) & $*$ & & \\
\hline & Nagar \& Singh (2019) & & $*$ & \\
\hline & Phau et al., (2009a) & & & $*$ \\
\hline & Phau et al., (2009b) & & & $*$ \\
\hline & Randhawa et al., (2015) & $*$ & & \\
\hline & Swami et al., (2009) & $*$ & & \\
\hline Material Happiness & Swami et al., (2009) & & $*$ & \\
\hline Novelty seeking & Phau \& Teah (2009) & & & $*$ \\
\hline $\begin{array}{l}\text { Openness to } \\
\text { Experience }\end{array}$ & Randhawa et al., (2015) & & & $*$ \\
\hline $\begin{array}{l}\text { Perception of } \\
\text { Business ethics }\end{array}$ & Lee \& Workman (2011) & & & $*$ \\
\hline \multirow{2}{*}{$\begin{array}{l}\text { Perceived } \\
\text { Behavioral control }\end{array}$} & Chiu \& Leng (2016) & 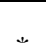 & & \\
\hline & Wu et al. (2019) & & & $*$ \\
\hline Perceived & Wu et al, (2019) & & $*$ & \\
\hline
\end{tabular}




\begin{tabular}{|c|c|c|c|c|}
\hline $\begin{array}{l}\text { counterfeit } \\
\text { detection }\end{array}$ & & & & \\
\hline \multirow[t]{2}{*}{ Performance risk } & Koay (2018) & & $*$ & \\
\hline & Riquelme et al., (2012) & & $*$ & \\
\hline Positive Emotions & Pratt \& Zeng (2019) & $*$ & & \\
\hline Personal Relevance & Pratt \& Zeng (2019) & & & * \\
\hline \multirow{2}{*}{ Prosecution risk } & Koay (2018) & & & * \\
\hline & Riquelme et al., (2012) & & & * \\
\hline \multirow[t]{2}{*}{ Psychological risk } & Koay (2018) & & & $*$ \\
\hline & Pueschel et al. (2016) & & $*$ & \\
\hline Realisms & Souiden et al., (2018) & $*$ & & \\
\hline $\begin{array}{l}\text { Religious } \\
\text { involvement }\end{array}$ & Souiden et al., (2018) & & * & \\
\hline Religious Beliefs & Souiden et al., (2018) & & $*$ & \\
\hline $\begin{array}{l}\text { Risk of } \\
\text { Disappointment }\end{array}$ & Hamelin et al., (2013) & & $*$ & \\
\hline \multirow{2}{*}{ Self-ambiguity } & Fernandes (2013) & $*$ & & \\
\hline & Teah et al., (2015) & & $*$ & \\
\hline $\begin{array}{l}\text { Sensitivity toward } \\
\mathrm{CF}\end{array}$ & Norum \& Cuno (2011) & & & $*$ \\
\hline Shame & Kim et al., (2009) & & & $*$ \\
\hline \multirow[t]{2}{*}{ Social Risk } & Biana \& Moutinho (2009) & & $*$ & \\
\hline & Koay (2018) & & $*$ & \\
\hline \multirow{3}{*}{$\begin{array}{l}\text { Value } \\
\text { consciousness }\end{array}$} & Fernandes (2013) & $*$ & & \\
\hline & Phau \& Tea (2009) & $*$ & & \\
\hline & Randhawa et al., (2015) & $*$ & & \\
\hline Variety Seeking & Nagar \& Singh (2019) & & $*$ & \\
\hline \multicolumn{5}{|l|}{ Product Based Factors } \\
\hline $\begin{array}{lr}\text { Attitude } & \text { towards } \\
\text { anti } & \text { counterfeit }\end{array}$ & Pratt \& Zeng (2019) & & $*$ & \\
\hline
\end{tabular}




\begin{tabular}{|c|c|c|c|c|}
\hline \multicolumn{5}{|l|}{ strategies } \\
\hline $\begin{array}{l}\text { Attitude towards the } \\
\text { original brand }\end{array}$ & Marticotte \& Arcand (2017) & & $*$ & \\
\hline Absence of Warrant & Hamelin et al., (2013) & & & $*$ \\
\hline Accessibility & Hamelin et al., (2013) & $*$ & & \\
\hline \multirow{2}{*}{$\begin{array}{l}\text { Brand attachment to } \\
\text { original }\end{array}$} & Kaufmann et al., (2016) & & & $*$ \\
\hline & Randhawa et al., (2015) & $*$ & & \\
\hline \multirow{2}{*}{$\begin{array}{l}\text { Brand } \\
\text { consciousness }\end{array}$} & Chiu \& Leng (2016) & & $*$ & \\
\hline & Jiang \& Shan (2016) & $*$ & & \\
\hline Brand Image & Bian \& Moutinho (2011) & & & \\
\hline \multirow{2}{*}{$\begin{array}{l}\text { Brand personality } \\
\text { of } \mathrm{CF}\end{array}$} & Bian \& Moutinho (2009) & $*$ & & \\
\hline & Bian \& Moutinho (2011) & $*$ & & \\
\hline $\begin{array}{l}\text { Counterfeit product } \\
\text { evaluation }\end{array}$ & Sharma \& Chan (2016) & * & & \\
\hline Design & Hamelin et al., (2013) & & $*$ & \\
\hline Economic Benefit & Kaufmann et al., (2016) & & & \\
\hline $\begin{array}{l}\text { Knowledge about } \\
\text { counterfeit products }\end{array}$ & Marcketti \& Shelley (2009) & $*$ & & \\
\hline Location & Pratt \& Zeng (2019) & $*$ & & \\
\hline \multirow[t]{2}{*}{ Perceived Benefits } & Bian \& Moutinho (2009) & $*$ & & \\
\hline & Bian \& Moutinho (2011) & $*$ & & \\
\hline $\begin{array}{l}\text { Perceived Corporate } \\
\text { Citizenship }\end{array}$ & Poddar et al., (2012) & $*$ & & \\
\hline $\begin{array}{l}\text { Perceived Quality } \\
\text { Difference }\end{array}$ & Poddar et al., (2012) & & $*$ & \\
\hline Price & Hamelin et al., (2013) & & $*$ & \\
\hline Price Difference & Poddar et al., (2012) & $*$ & & \\
\hline $\begin{array}{l}\text { Prior experience } \\
\text { with } \mathrm{CF}\end{array}$ & Riquelme et al., (2012) & $*$ & & \\
\hline \multirow[t]{2}{*}{ Product attribute } & Bian \& Moutinho (2009) & $*$ & & \\
\hline & Bian \& Moutinho (2011) & $*$ & & \\
\hline
\end{tabular}




\begin{tabular}{|c|c|c|c|c|}
\hline \multirow{2}{*}{$\begin{array}{l}\text { Product/ category } \\
\text { involvement }\end{array}$} & Bian \& Moutinho (2009) & & & $*$ \\
\hline & Bian \& Moutinho (2011) & & & $*$ \\
\hline \multirow[t]{2}{*}{ Product Knowledge } & Bian \& Moutinho (2009) & & & $*$ \\
\hline & Bian \& Moutinho (2011) & & & $*$ \\
\hline $\begin{array}{l}\text { Product } \\
\text { Performance }\end{array}$ & Phau et al., (2009b) & & & $*$ \\
\hline $\begin{array}{l}\text { Product Similarity } \\
\text { between } \mathrm{CF} \text { and } \\
\text { Geniune products }\end{array}$ & Marticotte \& Arcand (2017) & $*$ & & \\
\hline $\begin{array}{l}\text { Purchasing } \\
\text { Intention } \\
\text { originals }\end{array}$ & Kaufmann et al., (2016) & & $*$ & \\
\hline Quality & Hamelin et al., (2013) & $*$ & & \\
\hline Safety & Hamelin et al., (2013) & & $*$ & \\
\hline \multirow[t]{2}{*}{ Schadenfreude } & Marticotte \& Arcand (2017) & $*$ & & \\
\hline & Phau et al., (2009b) & & & $*$ \\
\hline Useful Life & Phau et al., (2009b) & & $*$ & \\
\hline Visibility & Hamelin et al., (2013) & & & $*$ \\
\hline \multicolumn{5}{|l|}{ Social Based Factors } \\
\hline Collectivism & Phau \& Teah (2009) & & & $*$ \\
\hline \multirow[t]{2}{*}{ Culture } & Pratt \& Zeng (2019) & & & $*$ \\
\hline & Lee \& Workman (2011) & $*$ & & \\
\hline Effects of others & Pratt \& Zeng (2019) & & & $*$ \\
\hline Face consciousness & Jiang \& Shan (2016) & $*$ & & \\
\hline $\begin{array}{l}\text { Information } \\
\text { Susceptibility }\end{array}$ & Phau \& Teah (2009) & & & $*$ \\
\hline $\begin{array}{l}\text { Normative } \\
\text { Susceptibility }\end{array}$ & Phau \& Teah (2009) & & & $*$ \\
\hline $\begin{array}{ll}\text { Public } & \text { self- } \\
\text { consciousness } & \end{array}$ & Kaufmann et al., (2016) & & & $*$ \\
\hline Sensitivity & Alfadl et al., (2014) & & & $*$ \\
\hline
\end{tabular}




\begin{tabular}{|c|c|c|c|c|}
\hline $\begin{array}{l}\text { negative social } \\
\text { consequence }\end{array}$ & Marticotte \& Arcand (2017) & & & $*$ \\
\hline Social adjustive & Ngo (2018) & $*$ & & \\
\hline Society Stigmatized & Alfadl et al., (2014) & & & $*$ \\
\hline \multirow{3}{*}{ Status consumption } & Phau et al., (2009a) & & & * \\
\hline & Phau et al., (2009b) & & & * \\
\hline & Phau \& Teah (2009) & $*$ & & \\
\hline \multirow{4}{*}{ Subjective norms } & Chiu \& Leng (2016) & $*$ & & \\
\hline & Fernandes (2013) & $*$ & & \\
\hline & Sharma \& Chan (2016) & & $*$ & \\
\hline & Wu et al., (2019) & $*$ & & \\
\hline $\begin{array}{l}\text { Value Expressive } \\
\text { Function }\end{array}$ & Ngo (2018) & & & $*$ \\
\hline \multicolumn{5}{|c|}{ Attitude Towards Counterfeit } \\
\hline \multirow{15}{*}{$\begin{array}{l}\text { Attitude Towards } \\
\text { Counterfeit }\end{array}$} & Bhatia (2018) & $*$ & & \\
\hline & Chiu \& Leng (2016) & $*$ & & \\
\hline & Jiang et al., (2019) & $*$ & & \\
\hline & Lee \& Workman (2011) & $*$ & & \\
\hline & Moon et al., (2018) & $*$ & & \\
\hline & Norum \& Cuno (2011) & $*$ & & \\
\hline & Phau et al., (2009a) & & & $*$ \\
\hline & Quoquab et al., (2017) & $*$ & & \\
\hline & Riquelme et al., (2012) & $*$ & & \\
\hline & Sondhi (2017) & $*$ & & \\
\hline & Souiden et al., (2018) & $*$ & & \\
\hline & Swami et al., (2009) & $*$ & & \\
\hline & Teah et al., (2015) & $*$ & & \\
\hline & Ting et al., (2016) & $*$ & & \\
\hline & Wu et al., (2019) & $*$ & & \\
\hline
\end{tabular}

Source: The Author

\subsubsection{Factors that affect consumer attitude towards counterfeit}


As mentioned before, the factors that have been examined to influence the counterfeit purchasing behavior can be classified into five categories, which are demographic-based factors, consumer trait-based factors, product and brandbased factors, social-based factors, and the last category is the impact of attitude on the intention toward counterfeits. However, not all studies have examined the effect of certain variables on the intention to buy this type of products, other studies that have explored the impact of these factors on buyer attitudes to purchase counterfeits and in some studies the relationship between attitude to buy counterfeit and consumer intention toward it (indirect effect on purchase intention) is investigated. The variables that have been examined in previous literature that influence attitude toward counterfeits can also be classified into three categories, which are the personal traits, product attribute, and socially based (Summarized in Table 5).

\subsubsection{The impact of individual characteristics on customer attitudes to buying counterfeits}

After reviewing the extracted articles one can note that the most studied (repeated) personal traits factors that influence attitude toward counterfeit are: ethical concerns (ethical consciousness, moral judgment, and moral equity), integrity, materialism, perceived risk, religiosity, and value consciousness.

Factors that are related to ethics like ethical concerns, ethical consciousness, moral judgment, and moral equity have also been observed to affect attitude towards counterfeit. Riquelme et al. (2012) stated that attitude influenced by ethical consciousness, and it interprets a meaningful percentage to explain the buyer's intention toward counterfeit products. Jiang et al., (2019) analyzed the 
effect of ethical and moral antecedents and ethical concerns on customer's attitudes to purchase counterfeit luxury goods. The results have been revealed that antecedents negatively affect consumer attitudes to buy counterfeit expensive brands. Another factor observed for affecting the attitude towards counterfeiting is integrity. Integrity is the degree of ethical consideration and adherence to the law by a person (Wang et al., 2005). Phau et al., (2009b) indicated that integrity is a crucial determinant in affecting the social implications of buyer attitudes to buying counterfeits luxury goods. Nevertheless, Phau et al., (2009b) considered that integrity is a significant factor to affect consumer buying intention. Concerning materialism which is classified as a personal trait, Phau et al. (2009a; 2009b) found that materialism had no effect on the attitude of customers to buy counterfeit luxury goods. Ting et al, (2016) revealed that materialism had no effect on the customer's attitudes to buy counterfeit luxury goods. Furthermore, Bhatia (2018) revealed that materialism is positively affected by consumer attitudes to buying these kinds of products. Another factor observed to affect attitude towards counterfeiting is perceived risk. Riquelme et al., (2012) found that attitude is negatively influenced by performance risk. Ting et al. (2016) revealed that the perceived risk had a negative association with buyer attitudes to buying counterfeit luxury goods. Bhatia (2018) revealed that perceived risks significantly associated the attitudes to buying counterfeit luxury products. Jiang et al., (2019) revealed that extrinsic religiosity and intrinsic religiosity, negatively affecting buyer attitudes to buy counterfeit brands. Riquelme et al., (2012) observed that value consciousness influences attitude. Similarly, Ting et al. (2016) revealed that 
value consciousness buyers are affected by their perceptions to buy counterfeit fashion brands, which ultimately leads to intention to buy. Bhatia (2018) also stated that value consciousness is positively related to the attitude of buyers to purchase counterfeit apparel products that eventually leads to intention to buy.

6.3.3.2 The impact of product-based factors on attitude to buying counterfeit goods

Moon et al., (2018) demonstrated that prior experience of purchasing counterfeit, product knowledge, and product attributes had a positive impact on the utilitarian attitude. Other streams of research like Swami et al., (2009) and Riquelme et al., (2012) have also shown that prior knowledge with counterfeit products affects attitudes to buying counterfeit products. Also, Bhatia 2018 indicated that brand conscious customers have no significant association with the attitudes to buy counterfeit apparel products.

6.3.3.3 The impact of social-based variables on customer's attitude to buying counterfeit goods

The most cited social factors examined in the extracted literature are collectivism ( Teah et al., 2015), descriptive and subjective norms (Riquelme et al., 2012), information and normative susceptibility (Teah et al., 2015; Ting et al., 2016; Moon et al., 2018), collectivism (Teah et al., 2015), social influence (Bhatia, 2018), and status consumption (Riquelme et al., 2012; Teah et al., 2015; Ting et al., 2016; Moon et al., 2018).

Teah et al., (2015) demonstrated that when investigating the predictors of attitudes towards luxury brand counterfeiting for both the China Chinese and Taiwan Chinese, The results indicated a positive relationship among 
collectivism and attitudes to purchasing the counterfeit products for the Chinese but not for the Chinese Taiwanese. Riquelme et al. (2012) reported that, in addition to collectivism, subjective and descriptive norms positively affect customer attitudes to buy counterfeit luxury brands. Similarly, a social factor has also affected the attitude toward buying counterfeiting (Ting et al., 2016; Bhatia 2018).

Phau \& Teah (2009 revealed that normative susceptibility, information susceptibility, had a lesser impact on the relationship of attitudes toward counterfeit goods; In addition, collectivism has been stated not to impact attitudes to buy counterfeit luxury goods. Another study by Pau \& Teah (2009) revealed that status consumption was the most substantial determinant affecting behavior, it indicating also those status buyers are more likely to buy counterfeit brand names. In addition, Moon et al., (2018) argued that status consumption a major positive predictor for hedonic and utilitarian attitudes.

Table 5 Summary of findings of the effect of factors on attitude towards counterfeit goods

\begin{tabular}{|l|l|l|l|l|}
\hline $\begin{array}{l}\text { Independent } \\
\text { Variables }\end{array}$ & Citations & Positive & Negative & $\begin{array}{l}\text { Not } \\
\text { Significant }\end{array}$ \\
\hline Personal Traits Factors & \multicolumn{2}{|l|}{} \\
\hline $\begin{array}{l}\text { Attitude towards } \\
\text { Lawfulness }\end{array}$ & Phau et al., (2009b) & & & $*$ \\
\hline & Quoquab et al., (2017) & & $*$ & \\
\hline Ethical concern & Jiang et al. (2019) & & $*$ & \\
\hline Ethical consciousness & Riquelme et al., (2012) & & & $*$ \\
\hline Ethical value & Quoquab et al., (2017) & & $*$ & \\
\hline
\end{tabular}




\begin{tabular}{|c|c|c|c|c|}
\hline Individual Deterrents & Viot (2014) & & $*$ & \\
\hline Individual & Viot (2014) & $*$ & & \\
\hline Motivations & & & & \\
\hline \multirow{5}{*}{ Integrity } & Phau et al., (2009a) & & $*$ & \\
\hline & Phau et al., (2009b) & $*$ & & \\
\hline & Jiang et al., (2019) & & $*$ & \\
\hline & Teah et al., (2015) & $*$ & & \\
\hline & Ting et al., (2016) & & & $*$ \\
\hline \multirow{5}{*}{ Materialism } & Bhatia (2018) & $*$ & & \\
\hline & Phau et al., (2009a) & & & $*$ \\
\hline & Phau et al., (2009b) & & & $*$ \\
\hline & Swami et al., (2009) & $*$ & & \\
\hline & Ting et al., (2016) & & & $*$ \\
\hline Novelty seeking & Moon et al., (2018) & $*$ & & \\
\hline Moral Judgement & Jiang et al., (2019) & & $*$ & \\
\hline \multirow[t]{2}{*}{ Perceived Risk } & Bhatia (2018) & & & $*$ \\
\hline & Ting et al., (2016) & & $*$ & \\
\hline \multirow[t]{2}{*}{ Personal gratification } & Phau \& Tea (2009) & & & $*$ \\
\hline & Teah et al., (2015) & & $*$ & \\
\hline \multirow[t]{2}{*}{ Religiosity } & Quoquab et al., 2017 & & $*$ & \\
\hline & Jiang et al., (2019) & & $*$ & \\
\hline \multirow{2}{*}{ Value consciousness } & Bhatia (2018) & $*$ & & \\
\hline & Riquelme et al., (2012) & $*$ & & \\
\hline \multicolumn{5}{|l|}{ Product Based Factors } \\
\hline Brand Consciousness & Bhatia (2018) & & & $*$ \\
\hline Product Appearance & Moon et al., (2018) & $*$ & & \\
\hline \multirow[t]{3}{*}{ Previous Experience } & Moon et al., (2018) & $*$ & & \\
\hline & Riquelme et al., (2012) & * & & \\
\hline & Swami et al., (2009) & $*$ & & \\
\hline Product Knowledge & Moon et al., (2018) & $*$ & & \\
\hline Store trustworthiness & Riquelme et al., (2012) & & & $*$ \\
\hline
\end{tabular}




\begin{tabular}{|c|c|c|c|c|}
\hline \multicolumn{5}{|l|}{ Social Based Factors } \\
\hline Collectivivsm & Teah et al., (2015) & $*$ & & \\
\hline Descriptive norms & Riquelme et al., (2012) & 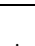 & & \\
\hline \multirow{3}{*}{$\begin{array}{l}\text { Information } \\
\text { Susceptibility }\end{array}$} & Moon et al., (2018) & & & $*$ \\
\hline & Teah et al., (2015) & & & $*$ \\
\hline & Ting et al., (2016) & & & $*$ \\
\hline $\begin{array}{l}\text { Normative } \\
\text { Susceptibility }\end{array}$ & Moon et al., (2018) & $*$ & & \\
\hline \multirow[t]{2}{*}{ Social Influence } & Bhatia (2018) & $*$ & & \\
\hline & Ting et al., (2016) & $*$ & & \\
\hline \multirow{4}{*}{ Status consumption } & Moon et al., (2018) & $*$ & & \\
\hline & Riquelme et al., (2012) & & & $*$ \\
\hline & Teah et al., (2015) & $*$ & & \\
\hline & Ting et al., (2016) & & $*$ & \\
\hline
\end{tabular}

Source: The Author

6.3.4 Mediator and moderator factors between purchase attitudes and intention toward counterfeit products

Several studies have examined the mediator and moderator effect of some variables between independent variables which influence either on consumer attitude to buy counterfeit or on intention/willingness to purchase counterfeit products (Summarized in Table 6)

Other research have analyzed the mediating effects of attitude to buying counterfeit among independent variable's and counterfeit purchase intention (Viot; 2014; Ting et al., 2016; Quoquab et al., 2017). Ting et al, (2016) Examined how consumer attitudes mediate between information susceptibility, value consciousness, perceived risk, integrity, the status of consumption and materialism, and consumers ' counterfeit buying intentions. The findings were 
that attitudes mediated between all the above-mentioned factors and counterfeit purchase intention excluding materialism, as attitude to buying counterfeiting did not mediate the relationship among materialism and the intention toward counterfeit brands. Quoquab et al., 2017 also revealed that the attitude to buy counterfeiting mediates between religiosity, ethical concern (value), attitude towards legitimacy and intention to buy counterfeit goods. Similarly, Viot (2014) investigated the mediating effect of counterfeit attitude between independent variable's societal effects, individual motives, and individual deterrents, and the dependent variable buying behavioral variables. The results were that the attitude towards counterfeit did not have any mediation effect on all of the above-mentioned independent variables. Riquelme et al. (2012) noted that previous purchases moderated the relation between customer attitudes and the intention toward counterfeit products.

Another mediator variable that was examined the degree of product involvement. Bian \& Moutinho (2011) proposed that the correlation between product involvement and the intention to purchase counterfeits is mediated by the way the customer perceives the brand image. Particularly, product involvement and product knowledge are independent variables and the brand image is a mediator variable. The results were that the image of the brand is not a mediator of the impact of participation/knowledge on the buying intention. Bhatia (2018) inspected the moderating effect of income, and the results were that income moderated the relationship between value-conscious customers, brand conscious customers, risk perception and attitude to buying counterfeit; however, income didn't have any moderating effect between materialism and 
attitude to buy counterfeit goods. However, a research by Swami et al., (2009) revealed that elderly participants showed less desire to purchase counterfeit products, although this effect was moderated by respondents ' consciousness of material values and the attitudes to buy counterfeit goods. Bian \& Moutinho (2011) suggested that consumer perception of the brand image mediates relationship between product engagement/awareness and the intention to purchase counterfeit products. Particularly, product engagement and product awareness are independent variables and the brand image is a mediator variable.

Table 6 Summary of the indirect relationships (Mediator/Moderator) effect

\begin{tabular}{|c|c|c|c|}
\hline $\begin{array}{l}\text { Publications } \\
\text { Citations }\end{array}$ & Independent variable & Mediator/ Moderator & Dependent variable \\
\hline \multirow{5}{*}{ Bhatia (2018) } & Value consciousness $(+)$ & \multirow{5}{*}{ Income (Moderator) } & \multirow{5}{*}{ Attitude Towards CF } \\
\hline & Brand Consciousness (+) & & \\
\hline & Perceived risk $(+)$ & & \\
\hline & Materialism (not significant) & & \\
\hline & $\begin{array}{l}\text { Social Influence (not } \\
\text { significant) }\end{array}$ & & \\
\hline \multirow{2}{*}{$\begin{array}{l}\text { Bian \& } \\
\text { Moutinho (2011) }\end{array}$} & $\begin{array}{l}\text { Consumers' perceptions of a } \\
\text { CBP }\end{array}$ & $\begin{array}{l}\text { Product Involvement (moderator). Not } \\
\text { significant }\end{array}$ & CF Purchase Intention \\
\hline & Product Knowledge & $\begin{array}{l}\text { Perceived Brand Image (Mediator)Not } \\
\text { significant) }\end{array}$ & CF Purchase Intention \\
\hline \multirow[t]{2}{*}{ Fan et al., (2013) } & Consumer value (NS) & - & \multirow{2}{*}{$\begin{array}{l}\text { CF Purchasing } \\
\text { Behavior }\end{array}$} \\
\hline & Consumer Involvement(S) & - & \\
\hline $\begin{array}{l}\text { Jiang \& Shan } \\
(2016)\end{array}$ & $\begin{array}{l}\text { Face consciousness } \\
\text { (Significant) }\end{array}$ & Brand consciousness (Mediateor) & $\begin{array}{l}\text { CF Purchase Intention } \\
\text { (Willingness) }\end{array}$ \\
\hline \multirow{2}{*}{$\begin{array}{l}\text { Kim et al., } \\
(2009)\end{array}$} & Guilt & Moral Judgement (Mediator). Supported & \multirow[t]{2}{*}{ CF Purchase Intention } \\
\hline & Shame & Moral Judgement (Mediator). Not significant & \\
\hline
\end{tabular}




\begin{tabular}{|c|c|c|c|}
\hline \multirow{3}{*}{$\begin{array}{l}\text { Ngo et al., } \\
(2018)\end{array}$} & Value Expressive Function & Product Involvement(+) (Moderator).Supported & \multirow[b]{2}{*}{ CF Purchase Intention } \\
\hline & Social Adjustive Function & $\begin{array}{lll}\text { Product Involvement } & \text { (Moderator). } & \text { Not } \\
\text { significant } & & \\
\end{array}$ & \\
\hline & Social Adjustive Function & Product Knowledge (+) (Moderator). Supported & CF Purchase Intention \\
\hline \multirow{3}{*}{$\begin{array}{l}\text { Orth et al., } \\
(2019)\end{array}$} & \multirow{3}{*}{ Moral Decoupling } & Positive Emotion (Moderator). Supported & \multirow{3}{*}{ CF Purchase Intention } \\
\hline & & Brand Attachment (Moderator). (Supported) & \\
\hline & & $\begin{array}{l}\text { Individual Involvement (Moderator). } \\
\text { (Supported) }\end{array}$ & \\
\hline \multirow{2}{*}{$\begin{array}{l}\text { Poddar et al., } \\
(2012)\end{array}$} & \multirow[b]{2}{*}{ Price Difference } & $\begin{array}{l}\text { Perceived Quality difference (Moderator). Not } \\
\text { significant }\end{array}$ & \multirow{2}{*}{ CF Purchase Intention } \\
\hline & & Perceived corporate citizenship (Moderator) (-) & \\
\hline \multirow{3}{*}{$\begin{array}{l}\text { Quoquab et al., } \\
\text { (2017) }\end{array}$} & Religiosity (-) & \multirow{3}{*}{ Attitude towards CF(Mediator) Supported } & \multirow{3}{*}{$\mathrm{CF}$ purchase Intention } \\
\hline & Ethical concern (value) (-) & & \\
\hline & Attitude towards legality (-) & & \\
\hline \multirow{3}{*}{$\begin{array}{l}\text { Randhawa et al., } \\
\text { (2015) }\end{array}$} & \multirow{3}{*}{$\begin{array}{l}\text { Self-Brand Connection } \\
\text { (Brand Attachment) }\end{array}$} & Value Consciousness $(+)$ (Moderator) & \multirow{3}{*}{$\begin{array}{l}\text { CF purchase intention } \\
\text { (Willingness }\end{array}$} \\
\hline & & Impulsive Buying (Not Supported) (Moderator) & \\
\hline & & Openness to Experience (-) (Moderator) & \\
\hline $\begin{array}{l}\text { Riquelme et al., } \\
\text { (2012) }\end{array}$ & Attitude towards counterfeit & $\begin{array}{l}\text { Previous purchase (mediator) } \\
\text { (Supported) }\end{array}$ & CF purchase intention \\
\hline \multirow{3}{*}{$\begin{array}{l}\text { Sharma \& Chan } \\
\text { (2017) }\end{array}$} & $\begin{array}{lr}\text { Negative } & \text { Impact of } \\
\text { Knowledge } & \text { Function } \\
\text { Supported } & \end{array}$ & Involvement level (Moderator) & \multirow{3}{*}{$\begin{array}{l}\text { Evaluation of a } \\
\text { counterfeit } \\
\text { product; }\end{array}$} \\
\hline & $\begin{array}{l}\text { Positive utilitarian effect } \\
\text { Supported }\end{array}$ & & \\
\hline & $\begin{array}{l}\text { Negative impact of value- } \\
\text { expressive } \\
\text { Supported }\end{array}$ & Consumption context (Moderator) & \\
\hline
\end{tabular}




\begin{tabular}{|c|c|c|c|}
\hline & $\begin{array}{l}\text { Positive impact of social- } \\
\text { adjustive } \\
\text { function Supported }\end{array}$ & & \\
\hline & $\begin{array}{l}\text { Value-expressive } \\
\text { (-) NS }\end{array}$ & \multirow{4}{*}{ Purchase motivation (Moderator) } & \\
\hline & $\begin{array}{l}\text { Social-adjustive (-) } \\
\text { functions } S\end{array}$ & & \\
\hline & Knowledge(+) NS & & \\
\hline & Utilitarian functions(+) $\mathrm{S}$ & & \\
\hline & Attitudinal functions & $\begin{array}{l}\text { Counterfeit Product Evaluation } \quad \text { (CPE) } \\
\text { (Mediator) Partial Support }\end{array}$ & $\begin{array}{l}\text { Intention to buy a } \\
\text { counterfeited product. }\end{array}$ \\
\hline \multirow{3}{*}{$\begin{array}{l}\text { Swami et al., } \\
(2009)\end{array}$} & \multirow{3}{*}{ Income } & $\begin{array}{l}\text { Conscientiousness } \\
\text { (Mediator) (Significant) }\end{array}$ & \multirow{3}{*}{$\begin{array}{l}\text { Desire to purchase } \\
\text { counterfeit brands }\end{array}$} \\
\hline & & $\begin{array}{l}\text { Material values } \\
\text { (Mediator) (Significant) }\end{array}$ & \\
\hline & & $\begin{array}{l}\text { Attitudes towards counterfeit products. } \\
\text { (Mediator) (Significant) }\end{array}$ & \\
\hline \multirow{7}{*}{$\begin{array}{l}\text { Ting et al., } \\
\text { (2016) }\end{array}$} & $\begin{array}{ll}\text { Information } & \text { Susceptibility } \\
\text { (Supported) } & \end{array}$ & \multirow{7}{*}{ Attitude to $\mathrm{CF}(+)$ (Mediator) } & \multirow{7}{*}{$\begin{array}{l}\text { CF Purchasing } \\
\text { Intention }\end{array}$} \\
\hline & $\begin{array}{ll}\text { Normative } & \text { Susceptibility } \\
\text { (Supported) } & \end{array}$ & & \\
\hline & $\begin{array}{ll}\text { Value } & \text { consciousness } \\
\text { (Supported) } & \end{array}$ & & \\
\hline & $\begin{array}{lll}\text { Perceived } & \text { Risk } \quad \text { (Not } \\
\text { Supported) } & & \end{array}$ & & \\
\hline & Integrity (Not Supported) & & \\
\hline & $\begin{array}{l}\text { Materialism } \quad \text { Not } \\
\text { Supported) }\end{array}$ & & \\
\hline & $\begin{array}{l}\text { Status Consumption (Not } \\
\text { Supported) }\end{array}$ & & \\
\hline
\end{tabular}




\begin{tabular}{|c|c|c|c|}
\hline \multirow{3}{*}{ Viot (2014) } & $\begin{array}{l}\text { Negative Societal impact } \\
\text { (Not Supported) }\end{array}$ & \multirow{3}{*}{ Attitude to $\mathrm{CF}(+)$. (Mediator) } & \multirow{3}{*}{$\begin{array}{l}\text { CF Purchasing } \\
\text { Intention }\end{array}$} \\
\hline & $\begin{array}{l}\text { Individual Motivations (Not } \\
\text { Supported) }\end{array}$ & & \\
\hline & $\begin{array}{l}\text { Individual deterrents (Not } \\
\text { Supported) }\end{array}$ & & \\
\hline \multirow{2}{*}{ Wu et al., (2019) } & $\begin{array}{l}\text { Attitude towards } \\
\mathrm{CF} \text { (Supported) }\end{array}$ & Perceived counterfeit detection (Moderator) & \multirow{2}{*}{ CF Purchase Intention } \\
\hline & $\begin{array}{l}\text { Subjective Norms (Not } \\
\text { Supported) }\end{array}$ & Perceived counterfeit detection (not significant) & \\
\hline \multirow{2}{*}{$\begin{array}{l}\text { Xiao et al., } \\
(2018)\end{array}$} & \multirow{2}{*}{$\begin{array}{l}\text { Actual-ideal Self- } \\
\text { Discrepancy }\end{array}$} & Self-monitoring (+) (Moderator) (Supported) & \multirow[b]{2}{*}{$\mathrm{CF}$ purchase intention } \\
\hline & & $\begin{array}{lllll}\text { perceived social } & \text { risk } & (-) & \text { (Moderator) } \\
\text { (Supported) } & & & & \end{array}$ & \\
\hline
\end{tabular}

Source: The Author

\section{Conclusion}

The current study reviewed the relevant literature that investigated the independent variables that affect customer buying behavior toward counterfeit products. These variables classified into five categories: demographic-based, customer trait-based, product-and brand-based, social-based and the effect of attitudes on counterfeit purchasing intention. As previously mentioned, studies are examining the relationships among independent variables (determinants) and consumer attitudes to buying counterfeit rather than the intention to buy counterfeit goods. Therefore, this research's contribution is to differentiate between the research examining the effect of dependent determinants (factors) on customer intention to buy counterfeits and the influence of these determinants on customer attitude to buy counterfeits, since usually in systematic literature about counterfeit there is no differentiation between the research which investigate those determinants on counterfeit purchase intention 
and the other studies that examined the influence of these factors on attitude to buy counterfeit products. In addition, this study also went deep to extract the extra indirect and additional relationships, and the mediators and moderators that were examined

When examining the extracted studies that have explored the demographicbased category, the results show a bit of controversy. Since examining the influence of age, some research indicated that age positively affects intention toward counterfeits (Riquelme et al., 2012). Where other studies stated that age negatively influence counterfeit purchase intention (Randhawa et al., 2015; Swami et al., 2009); however, most studies have suggested that age doesn't impact on consumer intention to buy counterfeits ( Biana \& Mountinho, 2009; Hamlin et al., 2013; Poddar et al., 2012, Pratt \& Zeng, 2019). In addition to education, some studies showed that education does positively influence consumer intention to buy counterfeits. (Riquelme et al., 2012), some showed that it negatively influences on counterfeit purchase intention (Pratt \& Zeng (2019), and the majority indicated that education does not influence CF purchase intention ( Biana \& Moutinho, 2009; Swami et al., 2009; Hamlin et al., 2013; Norum \& Cuno, 2011). Nevertheless, all extracted studies that have investigated income (Bian et al., 2016; Hamelin et al., 2013; Norum \& Cuno, 2011; Poddar et al., 2012; Riquelme et al., 2012). and gender's influence on CF purchase intention (Bian et al., 2016; Hamelin et al., 2013; Norum \& Cuno, 2011; Poddar et al., 2012; Pratt \& Zeng, 2019; Randhawa et al., 2015; Riquelme et al., 2012; Swami et al., 2009) and there was no evidence that both income and gender have any influence on $\mathrm{CF}$ purchase intention. 
Other studies have treated the subject from perspectives of personal traits. Personal-based traits that were repeatedly examined (three times or more) in the extracted articles are: materialism, ethical value, and judgment, value consciousness, integrity.

Randhawa et al. (2015) found that ethical value/moral intensity is negatively associated with counterfeit consumption. (Chaudhry \& Stumpf, 2011; Kozar \& Marcketti, 2011). Several studies suggest that integrity is negatively associated with counterfeit consumption. (Phau \&Teah, 2009) and materialism associated with counterfeit consumption. (Kozar \& Marcketti, 2011),

Bian \& Moutinho (2011) also revealed that the buyers of counterfeit products perceive counterfeit branded goods in terms of brand image as more styles, practicality, high quality and value for the price paid compared to non-buyers. From a product personality point of view, the buyers of counterfeit goods perceive it as being more charming, autonomous, trustworthy, secure, enthusiastic and traditional than non-buyers. For the social-based factors, which were studies such as social norms (Fernandes, 2013) were associated positively with the consumption of counterfeit goods. Controversial results regarding the roles of status consumption on counterfeit consumption are concluded (Phau \& Teah, 2009). In addition, the independent variables that affect counterfeit usage, normative susceptibility, self-ambiguity, social effect, have been studied. Additional research is required to verify these relationships. In addition, there is much research that has investigated the relationship between customer intention and attitude to buying counterfeit. All studies except one study (Phau et al., 2009a) concluded that the attitude to buying counterfeit products appears to 
impact the consumer intention to buy counterfeits. Nevertheless, as previously mentioned, studies have investigated the effect on the attitude to counterfeiting instead of analyzing the relationship between factors and counterfeit buying intentions a dependent variable. Therefore, consumer attitude to buying counterfeit is observed to be as a dependent variable. Findings for personal traits factors for materialism and integrity were controversial results, whereas for value-conscious all the extracted studies that have examined this factor have reported that value consciousness consumers have positive attitudes to buy counterfeits. For Product attributes, the factors' product appearance, product knowledge, prior experience with counterfeit have been reported to have a favorable impact on the attitude to buy counterfeit (Swami et al., 2009; Moon et al., 2018); however, the factors' brand consciousness and store trustworthiness didn't have any effect on attitude toward counterfeit.

Social influences also positively influence the attitude to buy counterfeit (Teah et al., 2015; Bhatia, 2018; Moon et al., 2018). However, information susceptibility does not affect attitude to buy counterfeits (Teah et al, 2015; Ting et al., 2016; Moon et al., 2018). Moreover, the status consumption factor had controversial results, some studies reported that status consumption positively influences (Teah et al., 2015; Moon et al., 2018), or negatively influence (Ting et al., 2016) attitude to buying counterfeit. Other studies have stated that status consumption doesn't influence attitude towards counterfeit (Riquelme et al., 2012). As for the studies that have investigated mediator and moderator effect, all research investigated the effect of both these mediator and moderator variables on the intention to buy counterfeits, excluding one research. (Bhatia 
2018) that has analyzed the moderator effect of income on customer attitude to buy counterfeits instead of intention to buy counterfeit as other studies did. One can conclude from the results of extracting articles from the period of 2009 till 2019 that have explored the factors that influence counterfeit consumption, that the most used mediator effect that has been tested on its potency to effect on counterfeit buying intention was the attitude to buy counterfeit (Phau \& Teah, 2009; Phau et al., 2009; Viot, 2014; Ting et al., 2016; Quoquab et al., 2017). However the results indicate that attitude toward counterfeit does not have to mediate between religiosity, ethical concern, attitude towards lawfulness and counterfeit buying intention (Quoquab et al., 2017), also it doesn't mediate between perceived risk, integrity, status consumption, materialism, and counterfeit purchase intention; however, it does have a mediator effect between information susceptibility, normative susceptibility and value consciousness (Ting et al., 2016).

In conclusion, this paper's aimed to apply for a systematic literature review on articles that have examined the factors from the demand side that affect counterfeit consumption. This paper's contribution was that it differentiates between the articles from the years 2009 till 2019 that have explored the factors (demand-side) affecting either counterfeit purchase intention or attitude toward counterfeit, thus it differentiates between which independent variable that was examined. In addition, it shed light on the mediator and moderator variables that have been used from the extracted articles.

\section{Ideas for future studies}


The process of reviewing the literature in marketing indicates that there are a substantial number of suggestions for future studies, either in methodological or in thematic, in regard to the independent variables. In that point of view, methodologically, the large percentage (81 percent) of demand-side counterfeiting research took a quantitative type of research. Concerning the generalization of the findings, quantitative research is quite confident. Moreover, in most of the research, the undiscovered nature of the consumer behavior to buy counterfeit products is criticized in those quantitative studies, because in this type of research it is insufficient to discover that variables that clarify the cognitive processes that lead consumers to lean on counterfeit products.

Therefore, qualitative research is recommended to provide further valuable insights to academic researchers. Focus groups may be a useful marketing research tool for exploring the variables and factors that drive the buyer intention and attitudes toward counterfeits. Furthermore, it is generally recommended that these qualitative researches be conducted across different samples, such as different levels of income. In particular, one imported domain of research that has not been systematically properly studied is the possible differentiation among consumer behavior in less developed and in the developed countries with regard to the intention and the attitudes to buying counterfeit products. Another important comparison is described as buyers who simultaneously use genuine and counterfeit products. These kinds of buyers are critically significant to analyze the consumer buying behavior and are important 
for the selection of genuine brands for certain market segments and counterfeits for other segments.

However, analyzing the demand side of counterfeiting reveals that more than half of the studies didn't rely on a certain theory of their research as a way to explain consumer behavior toward counterfeiting. Moreover, most of the studies adhered to a specific theory were about 12 of studies, and those studies relied on theory of reasoned action and theory of planned behavior. This indicates the important role played by those couple of theories to understand consumer attitudes and intention. this means that adopting other different theories to explain consumer behavior toward counterfeiting may help to contribute more in understanding consumer behavior.

\section{References}

Ahmad, N., Shamsi, A., \& Hussain, S. (2016). Impact of Counterfeit Products on Consumer Buying Behavior: Empirical Investigation form Karachiites. Grassroots, 50(1). 
Albers-Miller, N. D. (1999). Consumer misbehavior: why people buy illicit goods. Journal of Consumer Marketing, 16(3), 273-287. doi:10.1108/07363769910271504

Alfadl, A. A., Ibrahim, M. I., \& Hassali, M. A. (2014). How ethics influence intentions to buy counterfeit drugs: perceptions of policymakers, community pharmacists and consumers in Sudan. Journal of Pharmaceutical Health Services Research, 5(3), 181-186. doi:10.1111/jphs.12062

Amine, L. S., \& Magnusson, P. (2007). Cost-Benefit Models of Stakeholders in the Global Counterfeiting Industry and Marketing Response Strategies. Multinational Business Review, 15(2), 63-86. doi:10.1108/1525383x200700008 Augusto de Matos, C., Trindade Ituassu, C., \& Vargas Rossi, C. A. (2007). Consumer attitudes toward counterfeits: a review and extension. Journal of Consumer Marketing, 24(1), 36-47. doi:10.1108/07363760710720975

Baruönü Latif, Ö., Kaytaz Yiğit, M., \& Kirezli, Ö. (2018). A review of counterfeiting research on demand side: Analyzing prior progress and identifying future directions. The Journal of World Intellectual Property, 21(56), 458-480. doi:10.1111/jwip.12115

Belk, R. W. (1985). Materialism: Trait Aspects of Living in the Material World. Journal of Consumer Research, 12(3), 265. doi:10.1086/208515

Bhatia, V. (2018). Examining consumers' attitude towards purchase of counterfeit fashion products. Journal of Indian Business Research, 10(2), 193207. doi:10.1108/jibr-10-2017-0177 
Bian, X., \& Moutinho, L. (2009). An investigation of determinants of counterfeit purchase consideration. Journal of Business Research, 62(3), 368378. doi:10.1016/j.jbusres.2008.05.012

Bian, X., \& Moutinho, L. (2011a). Counterfeits and branded products: Effects of counterfeit ownership. Journal of Product \& Brand Management, 20(5), 379-393. doi:10.1108/10610421111157900

Bian, X., \& Moutinho, L. (2011b). The role of brand image, product involvement, and knowledge in explaining consumer purchase behaviour of counterfeits. European Journal of Marketing, 45(1/2), 191-216. doi:10.1108/03090561111095658

Bian, X., Wang, K., Smith, A., \& Yannopoulou, N. (2016). New insights into unethical counterfeit consumption. Journal of Business Research, 69(10), 42494258. doi:10.1016/j.jbusres.2016.02.038

Bradley P. Evans, Richard G. Starr, Roderick J. Brodie, (2019) "Counterfeiting: conceptual issues and implications for branding", Journal of Product \& Brand Management, https://doi.org/10.1108/JPBM-12-2017-1706

Cesareo, L., \& Stöttinger, B. (2015). United we stand, divided we fall: How firms can engage consumers in their fight against counterfeits. Business Horizons, 58(5), 527-537. doi:10.1016/j.bushor.2015.05.007

Chaudhry, P. E., \& Stumpf, S. A. (2011). Consumer complicity with counterfeit products. Journal of Consumer Marketing, 28(2), 139-151. doi:10.1108/07363761111115980 
Chaudhry, P. E., \& Walsh, M. G. (1996). An assessment of the impact of counterfeiting in international markets: The piracy paradox persists. The Columbia Journal of World Business, 31(3), 34-48. doi:10.1016/s00225428(96)90039-3

Cheung, W., \& Prendergast, G. (2006). Buyers' perceptions of pirated products in China. Marketing Intelligence \& Planning, 24(5), 446-462. doi:10.1108/02634500610682854

Chiu, W., \& Leng, H. K. (2016). Consumers' intention to purchase counterfeit sporting goods in Singapore and Taiwan. Asia Pacific Journal of Marketing and Logistics, 28(1), 23-36. doi:10.1108/apjml-02-2015-0031 Cho, S., Fang, X., \& Tayur, S. (2015). Combating Strategic Counterfeiters in Licit and Illicit Supply Chains. Manufacturing \& Service Operations Management, 17(3),273-289. doi:10.1287/msom.2015.0524 Colicchia, C., \& Strozzi, F. (2012). Supply chain risk management: a new methodology for a systematic literature review. Supply Chain Management: An International Journal, 17(4), 403-418. doi:10.1108/13598541211246558 Davidson, A., Nepomuceno, M. V., \& Laroche, M. (2017). Shame on You: When Materialism Leads to Purchase Intentions Toward Counterfeit Products. Journal of Business Ethics, 155(2), 479-494. doi:10.1007/s10551-017-3479-5

Denyer, D., \& Tranfield, D. (2009). Producing a systematic review. In D. A. Buchanan \& A. Bryman (Eds.), The Sage handbook of organizational research methods, 671-689. Sage Publications Ltd.

Eisend, M., Hartmann, P., \& Apaolaza, V. (2017). Who Buys Counterfeit Luxury Brands? A Meta-Analytic Synthesis of Consumers in Developing and 
Developed Markets. Journal of International Marketing, 25(4), 89-111. doi:10.1509/jim.16.0133

Eisend, M., \& Schuchert-Guler, P. (2006). Explaining counterfeit purchases: A review and preview. Academy of Marketing Science Review, 12, 1-22.

EUIPO. (2016, December 5). EUR 83 billion and 790000 jobs lost every year across the EU due to counterfeiting and piracy. Retrieved from https://euipo.europa.eu/ohimportal/en/news/-/action/view/3360773

Fan, W., Lan, C., Huang, Y., \& Chang, R. (2013). A study on purchasing behavior of teenagers in Taiwan: example of counterfeit goods. Journal of Applied Social Psychology, 43(6), 1289-1300. doi:10.1111/jasp.12092

Fawcett, S. E., Waller, M. A., Miller, J. W., Schwieterman, M. A., Hazen, B. T., \& Overstreet, R. E. (2014). A Trail Guide to Publishing Success: Tips on Writing Influential Conceptual, Qualitative, and Survey Research. Journal of Business Logistics, 35(1), 1-16. doi:10.1111/jbl.12039

Fernandes, C. (2013). Analysis of counterfeit fashion purchase behaviour in UAE. Journal of Fashion Marketing and Management: An International Journal, 17(1), 85-97. doi:10.1108/13612021311305155

Forsythe, S. M., \& Shi, B. (2003). Consumer patronage and risk perceptions in Internet shopping. Journal of Business Research, 56(11), 867-875. doi:10.1016/s0148-2963(01)00273-9

Gentry, J. W., Putrevu, S., Shultz, C., \& Commuri, S. (2001). How now Ralph Lauren? The separation of brand and product in a counterfeit culture. Advances in Consumer Research, 28, 258-265. 
Gentry, J. W., Putrevu, S., \& Shultz, C. J. (2006). The effects of counterfeiting on consumer search. Journal of Consumer Behaviour, 5(3), 245-256. doi:10.1002/cb.176

Green, R. T., \& Smith, T. (2002). Executive Insights: Countering Brand Counterfeiters. Journal of International Marketing, 10(4), 89-106. doi:10.1509/jimk.10.4.89.19551

Hamelin, N., Nwankwo, S., \& El Hadouchi, R. (2012). 'Faking brands': Consumer responses to counterfeiting. Journal of Consumer Behaviour, 12(3), 159-170. doi:10.1002/cb.1406

Harun,A., Bledram,N. A. A. R., Suki,N. M., \& Hussein,Z. (2012). Why customers don't buy counterfeit of luxury brands? understanding the effects of personality: Perceived quality and attitude on unwillingness to purchase. Labuan e-Journal of Muamalat and Society, 6,14-29.

Herstein, R., Drori, N., Berger, R., \& Barnes, B. R. (2015). Anticounterfeiting strategies and their influence on attitudes of different counterfeit consumer types. Psychology \& Marketing, 32(8), 842-859. doi:10.1002/mar.20822

Jesson, R., McNaughton, S., \& Parr, J. M. (2011). Drawing on intertextuality in culturally diverse classrooms: Implications for transfer of literacy knowledge. English Teaching: Practice \& Critique,10(2), 65-77

Jiang, L., \& Shan, J. (2016). Counterfeits or Shanzhai? The Role of Face and Brand Consciousness in Luxury Copycat Consumption. Psychological Reports, 119(1), 181-199. doi:10.1177/0033294116659316

Jiang, Y., Miao, M., Jalees, T., \& Zaman, S. I. (2019). Analysis of the moral mechanism to purchase counterfeit luxury goods: evidence from China. Asia 
Pacific Journal of Marketing and Logistics, 31(3), 647-669. doi:10.1108/apjml05-2018-0190

Kamalahmadi, M., \& Parast, M. M. (2016). A review of the literature on the principles of enterprise and supply chain resilience: Major findings and directions for future research. International Journal of Production Economics, 171, 116-133. doi:10.1016/j.ijpe.2015.10.023

Kaufmann, H. R., Petrovici, D. A., Filho, C. G., \& Ayres, A. (2016). Identifying moderators of brand attachment for driving customer purchase intention of original vs counterfeits of luxury brands. Journal of Business Research, 69(12), 5735-5747. doi:10.1016/j.jbusres.2016.05.003

Kian Yeik Koay, (2018) "Understanding consumers' purchase intention towards counterfeit luxury goods: An integrated model of neutralisation techniques and perceived risk theory", Asia Pacific Journal of Marketing and Logistics, Vol. 30 Issue: 2, pp.495-516, https://doi.org/10.1108/

APJML-05-2017-0100

Kim, J., Hyeon Jeong Cho, \& Johnson, K. K. (2009). Influence of Moral Affect, Judgment, and Intensity on Decision Making Concerning Counterfeit, Gray-Market, and Imitation Products. Clothing and Textiles Research Journal, 27(3), 211-226. doi:10.1177/0887302x08327993

Koay, K. (2018). Understanding consumers' purchase intention towards counterfeit luxury goods: an integrated model of neutralisation techniques and perceived risk theory. Asia Pacific Journal of Marketing and Logistics. doi:10.1108/apjml-05-2017-0100 
Kozar, J. M., \& Marcketti, S. B. (2011). Examining ethics and materialism with purchase of counterfeits. Social Responsibility Journal, 7(3), 393-404. doi:10.1108/17471111111154536

Lee, S., \& Workman, J. E. (2011). Attitudes Toward Counterfeit Purchases and Ethical Beliefs Among Korean and American University Students. Family and Consumer Sciences Research Journal, 39(3), 289-305. doi:10.1111/j.15523934.2010.02067.x

Linnenluecke, M. K., Verreynne, M., De Villiers Scheepers, M. J., \& Venter, C. (2017). A review of collaborative planning approaches for transformative change towards a sustainable future. Journal of Cleaner Production, 142, 32123224. doi:10.1016/j.jclepro.2016.10.148

Marcketti, S. B., \& Shelley, M. C. (2009). Consumer concern, knowledge and attitude towards counterfeit apparel products. International Journal of Consumer Studies, 33(3), 327-337. doi:10.1111/j.1470-6431.2009.00748.x Marticotte, F., \& Arcand, M. (2017). Schadenfreude, attitude and the purchase intentions of a counterfeit luxury brand. Journal of Business Research, 77, 175183. doi:10.1016/j.jbusres.2016.12.010

Martinez, L. F., \& Jaeger, D. S. (2016). Ethical decision making in counterfeit purchase situations: the influence of moral awareness and moral emotions on moral judgment and purchase intentions. Journal of Consumer Marketing, 33(3), 213-223. doi:10.1108/jcm-04-2015-1394

Mitchell, V. (1999). Consumer perceived risk: conceptualisations and models. European Journal of Marketing, 33(1/2), 163-195. doi:10.1108/03090569910249229 
Moon, M. A., Javaid, B., Kiran, M., Awan, H. M., \& Farooq, A. (2018). Consumer perceptions of counterfeit clothing and apparel products attributes. Marketing Intelligence \& Planning, 36(7), 794-808. doi:10.1108/mip-11-20170272

Nagar, K., \& Singh, V. P. (2019). Modelling the Effects of Materialism, Ethics and Variety-Seeking Behaviour on Counterfeit Consumption of Young Consumers. Global Business Review, 097215091881801.

doi:10.1177/0972150918818015

. https://www.netnames.com/assets/shared/whitepaper/pdf/NetNamesCounterfeiting-Report-A4 2015.pdf. Accessed 16 April 2019

Ngo, L. V., Northey, G., Tran, Q., \& Septianto, F. (2018). The Devil might wear Prada, but Narcissus wears counterfeit Gucci! How social adjustive functions influence counterfeit luxury purchases. Journal of Retailing and Consumer Services, 52. doi:10.1016/j.jretconser.2018.09.003

Nia, A., \& Lynne Zaichkowsky, J. (2000). Do counterfeits devalue the ownership of luxury brands? Journal of Product \& Brand Management, 9(7), 485-497. doi:10.1108/10610420010351402

Norum, P. S., \& Cuno, A. (2011). Analysis of the demand for counterfeit goods. Journal of Fashion Marketing and Management: An International Journal, 15(1), 27-40. doi:10.1108/13612021111112322

OECD/EUIPO (2016), Trade in Counterfeit and Pirated Goods: Mapping the Economic Impact, OECD Publishing, Paris.http://dx.doi.org/10.1787/9789264252653-en 
Omeraki Çekirdekci, Ş., \& Baruonu Latif, F. O. (2019). Users and non-users of counterfeits: Motivations, emotional outcomes and neutralization processes. Journal of Product \& Brand Management. doi:10.1108/jpbm-06-2018-1926

Orth, U. R., Hoffmann, S., \& Nickel, K. (2019). Moral decoupling feels good and makes buying counterfeits easy. Journal of Business Research, 98, 117125. doi:10.1016/j.jbusres.2019.01.001

Penz, E., \& Stottinger, B. (2005). Forget the "Real" Thing-Take the Copy! An Explanatory Model for the Volitional Purchase of Counterfeit Products. Advances in Consumer Research, 32, 568-575.

Phau, I., Sequeira, M., \& Dix, S. (2009a). To buy or not to buy a "counterfeit" Ralph Lauren polo shirt. Asia-Pacific Journal of Business Administration, 1(1), 68-80. doi:10.1108/17574320910942187

Phau, I., Sequeira, M., \& Dix, S. (2009b). Consumers' willingness to knowingly purchase counterfeit products. Direct Marketing: An International Journal, 3(4), 262-281. doi:10.1108/17505930911000865

Phau, I., \& Teah, M. (2009). Devil wears (counterfeit) Prada: a study of antecedents and outcomes of attitudes towards counterfeits of luxury brands. Journal of Consumer Marketing, 26(1), 15-27. doi:10.1108/07363760910927019

Poddar, A., Foreman, J., Banerjee, S. (., \& Ellen, P. S. (2012). Exploring the Robin Hood effect: Moral profiteering motives for purchasing counterfeit products. Journal of Business Research, 65(10), 1500-1506. doi:10.1016/j.jbusres.2011.10.017 
Pratt, S., \& Zeng, C. Y. (2019). The economic value and determinants of tourists' counterfeit purchases: The case of Hong Kong. Tourism Economics, 26(1), 155-178. doi:10.1177/1354816619834482

Pueschel, J., Chamaret, C., \& Parguel, B. (2017). Coping with copies: The influence of risk perceptions in luxury counterfeit consumption in GCC countries. Journal of Business Research, 77, 184-194. doi:10.1016/j.jbusres.2016.11.008

Quoquab, F., Pahlevan, S., Mohammad, J., \& Thurasamy, R. (2017). Factors affecting consumers' intention to purchase counterfeit product. Asia Pacific Journal of Marketing and Logistics, 29(4), 837-853. doi:10.1108/apjml-092016-0169

Randhawa, P., Calantone, R. J., \& Voorhees, C. M. (2015). The pursuit of counterfeited luxury: An examination of the negative side effects of close consumer-brand connections. Journal of Business Research, 68(11), 23952403. doi:10.1016/j.jbusres.2015.02.022

Richins, M. L., \& Rudmin, F. W. (1994). Materialism and economic psychology. Journal of Economic Psychology, 15(2), 217-231

Riquelme, H. E., Mahdi Sayed Abbas, E., \& Rios, R. E. (2012). Intention to purchase fake products in an Islamic country. Education, Business and Society: Contemporary Middle Eastern Issues, 5(1), 6-22. doi:10.1108/17537981211225835

Sharma, P., \& Chan, R. Y. (2016). Demystifying deliberate counterfeit purchase behaviour. Marketing Intelligence \& Planning, 34(3), 318-335. doi:10.1108/mip-12-2014-0228 
Sharma, P., \& Chan, R. Y. (2017). Exploring the Role of Attitudinal Functions in Counterfeit Purchase Behavior via an Extended Conceptual Framework. Psychology \& Marketing, 34(3), 294-308. doi:10.1002/mar.20989

Sondhi, N. (2017). Scale development \& validation for assessing attitude towards counterfeit luxury. Procedia Computer Science, 122, 206-213. doi:10.1016/j.procs.2017.11.362

Souiden, N., Ladhari, R., \& Zarrouk Amri, A. (2018). Is buying counterfeit sinful? Investigation of consumers' attitudes and purchase intentions of counterfeit products in a Muslim country. International Journal of Consumer Studies, 42(6), 687-703. doi:10.1111/ijcs.12466

Spink, J., \& Moyer, D. C. (2011). Defining the Public Health Threat of Food Fraud. Journal of Food Science, 76(9), R157-R163. doi:10.1111/j.17503841.2011.02417.x

Spink, J., Moyer, D. C., Park, H., \& Heinonen, J. A. (2013). Defining the types of counterfeiters, counterfeiting, and offender organizations. Crime Science, 2(1). doi:10.1186/2193-7680-2-8

Staake, T., Thiesse, F., \& Fleisch, E. (2009). The emergence of counterfeit trade: a literature review. European Journal of Marketing, 43(3/4), 320-349. doi:10.1108/03090560910935451

Stevenson, M., \& Busby, J. (2015). An exploratory analysis of counterfeiting strategies. International Journal of Operations \& Production Management, 35(1), 110-144. doi:10.1108/ijopm-04-2012-0174

Sunitha, T., Frank Sunil Justus, T., \& Ramesh, M. (2012). Determinants of Perceived Risk in Purchase of Car. Pacific Business Review, 5(2). 
Swami, V., Chamorro-Premuzic, T., \& Furnham, A. (2009). Faking it: Personality and individual difference predictors of willingness to buy counterfeit goods. The Journal of Socio-Economics, 38(5), 820-825. doi:10.1016/j.socec.2009.03.014

Tang, F., Tian, V., \& Zaichkowsky, J. (2014). Understanding counterfeit consumption. Asia Pacific Journal of Marketing and Logistics, 26(1), 4-20. doi:10.1108/apjml-11-2012-0121

Teah, M., Phau, I., \& Huang, Y. (2015). Devil continues to wear "counterfeit" Prada: a tale of two cities. Journal of Consumer Marketing, 32(3), 176-189. doi:10.1108/jcm-03-2014-0908

Ting, M., Goh, Y., \& Isa, S. M. (2016). Determining consumer purchase intentions toward counterfeit luxury goods in Malaysia. Asia Pacific

Management Review, 21(4), 219-230. doi:10.1016/j.apmrv.2016.07.003

Toklu, I. T., \& Baran, S. (2017). Attitude towards Counterfeit of Luxury Brands: A Research on Consumers in Turkey. International Journal of Academic Research in Business and Social Sciences, 7(11). doi:10.6007/ijarbss/v7-i11/3503

Tranfield, D., Denyer, D., \& Smart, P. (2003). Towards a Methodology for Developing Evidence-Informed Management Knowledge by Means of Systematic Review. British Journal of Management, 14(3), 207-222. doi:10.1111/1467-8551.00375

Trinh, V., \& Phau, I. (2012). The overlooked component in the consumption of counterfeit luxury brands studies: Materialism - A literature review. Contemporary Management Research, 8(3). doi:10.7903/cmr.11156 
Tukamuhabwa, B. R., Stevenson, M., Busby, J., \& Zorzini, M. (2015). Supply chain resilience: definition, review and theoretical foundations for further study. International Journal of Production Research, 53(18), 5592-5623. doi:10.1080/00207543.2015.1037934

Viot, C., Le Roux, A., \& Krémer, F. (2014). Attitude towards the purchase of counterfeits: Antecedents and effect on intention to purchase. Recherche et Applications en Marketing (English Edition), 29(2), 3-31. doi:10.1177/2051570714533474

Wang, E. S. (2015). Different Effects of Utilitarian and Hedonic Benefits of Retail Food Packaging on Perceived Product Quality and Purchase Intention. Journal of Food Products Marketing, 23(3), 239-250. doi:10.1080/10454446.2014.885867

Wang, F., Zhang, H., Zang, H., \& Ouyang, M. (2005). Purchasing pirated software: an initial examination of Chinese consumers. Journal of Consumer Marketing, 22(6), 340-351. doi:10.1108/07363760510623939

Wilcox, K., Kim, H. M., \& Sen, S. (2009). Why Do Consumers Buy Counterfeit Luxury Brands?. Journal of Marketing Research, 46(2), 247-259. doi:10.1509/jmkr.46.2.247

Wu, G. J., Bagozzi, R. P., Anaza, N. A., \& Yang, Z. (2019). A goal-directed interactionist perspective of counterfeit consumption. European Journal of Marketing, 53(7), 1311-1332. doi:10.1108/ejm-07-2017-0455

Xiao, J., Li, C., \& Peng, L. (2018). Cross-cultural effects of self-discrepancy on the consumption of counterfeit branded luxuries. Asia Pacific Journal of Marketing and Logistics, 30(4), 972-987. doi:10.1108/apjml-12-2017-0341 